Ecclesia. Studia z Dziejów Wielkopolski t. 13 (2018)

doi: 10.14746/e.2018.13.4

SALEZY BOGUMIL TOMCZAK

Klasztor Franciszkanów w Poznaniu

\title{
Kościól św. Franciszka z Asyżu i klasztor Franciszkanów w Poznaniu w latach 1947-1957
}

\section{Zarys historii kościoła św. Franciszka z Asyżu i klasztoru Franciszkanów w Poznaniu}

Duchowi synowie św. Franciszka z Asyżu są obecni w Poznaniu od pięciuset sześćdziesięciu trzech lat. W 1455 r. przybyli do tego miasta bracia mniejsi obserwanci, zwani w Polsce bernardynami ${ }^{1}$. Byli to: Gabriel z Werony $^{2}$, przełożony wikariatu austriacko-czesko-polskiego i kilku towarzyszących mu braci. Do stolicy Wielkopolski przybyli, aby zbadać możliwości osiedlenia się w tym mieście. Jan z Komorowa ${ }^{3}$, historyk i kronikarz zakonu,

${ }^{1}$ W 1453 roku na zaproszenie króla polskiego Kazimierza Jagiellończyka i kardynała Zbigniewa Oleśnickiego przybył do Krakowa Jan Kapistran, jeden z przywódców ruchu obserwanckiego w Zakonie Braci Mniejszych, wielki kaznodzieja i apostoł Europy (ogłoszony świętym 1724). Pod wpływem jego płomiennych kazań głoszonych przez kilka miesięcy na rynku krakowskim zgłosiło się do niego kilkadziesiąt osób, przeważnie studentów i profesorów Wszechnicy Jagiellońskiej, z prośbą o przyjęcie do zakonu. Jan Kapistran wybrał spośród nich tych, których uznał za zdatnych i godnych i założył dla nich u podnóża Wawelu klasztor pw. św. Bernardyna ze Sieny. Mieszkańcy Krakowa zaczęli tych zakonników nazywać „braćmi od św. Bernardyna” albo po prostu „bernardynami”. Tak narodziła się popularna nazwa na określenie polskich braci mniejszych obserwantów.

${ }^{2}$ Gabriel z Werony, właściwie Gabriele Rangoni, ur. 1410, do Zakonu Braci Mniejszych wstąpił w weneckiej prowincji obserwantów, był jednym z najbliższych współpracowników Jana Kapistrana, wikariuszem wikarii austro-czesko-polskiej (1455-1561), później biskupem Transilvani (1472), arcybiskupem Agria (1475), zmarł w 1486, pochowany został w kaplicy św. Bonawentury na Ara Coeli w Rzymie.

${ }^{3}$ Jan z Komorowa (Komorowski), h. Korczak, ur. ok. 1465, zm. 1536, historyk zakonu, gwardian w Wilnie, dwukrotnie w Warszawie i Poznaniu, trzykrotnie prowincjał, dwa razy uczestniczył w kapitułach generalnych (w Rzymie i Lyonie), autor dwóch kronik zakonnych, reprezentujących wysoki poziom piśmiennictwa historycznego: Tractatus cronicae Fratrum Minorum Observantium a tempore Constanciensis Consilii et specialiter de Provinciae Poloniae (wydana drukiem w 1873) i Memoriale Ordinis Fratrum Minorum, wydana drukiem w 1886 w V tomie serii „Monumenta 
tak na ten temat pisał w swojej kronice: „Tegoż roku $1455 \mathrm{w}$ jednym tygodniu zostały przyjęte przez o. Gabriela z Werony miejsca w Poznaniu, Kościanie i Wschowie. Albowiem pobożny lud pod najprzewielebniejszym ks. Andrzejem [z Bnina $]^{4}$, biskupem poznańskim, pragnął mieć braci z powodu ich świętego życia i wzorowości. Biskup ten zawsze darzył braci serdecznym przywiązaniem. Biskup ten to, będąc już sterany wiekiem i cierpiąc na nogi, nasz kościół w Poznaniu z podziwem swojej kurii z wielką uroczystością poświęcił. Miejsce zaś pod klasztor poznański ofiarował pan Maciej Czarny, obywatel poznański" "5. Fundacja w Grodzie Przemysła została przyjęta na kapitule w Ołomuńcu we wspomnianym 1455 r. Główny darczyńca, Maciej Czarny, formalnej darowizny na rzecz bernardynów dokonał 28 X 1456 r., a bp Andrzej z Bnina zatwierdził ją $10 \mathrm{~V} 1457 \mathrm{r}$. Zakonnicy sprowadzeni do Poznania zamieszkali początkowo w kilku lichych domkach, jakie im ofiarował Maciej Czarny. Uroczyste wprowadzenie bernardynów w otoczeniu miejscowego duchowieństwa i wiernych nastąpiło w samo Boże Narodzenie 25 XII 1457 r. Tymczasowy klasztor, w którym zamieszkali pierwsi bracia, był „lichą drewnianą budowlą”. Nie lepiej przedstawiał się drewniany kościółek, jaki zbudowano w 1458 r. Służył on przede wszystkim zakonnikom do odprawiania nabożeństw i modlitw wspólnotowych, natomiast z powodu ciasnoty nie nadawał się do celów duszpasterskich. Pierwsi przełożeni klasztoru poznańskiego pochodzenia niemieckiego hamowali rozwój placówki pod względem materialnym. Powołując się na zakonne ubóstwo, nie zgadzali się na budowę murowanych budynków, a jedynie na drewniane lub co najwyżej z tzw. pruskiego muru, mimo że biskup miejscowy Andrzej z Bnina, bardzo życzliwy zakonnikom, niemal żądał, aby zbudowano solidniejszy kościół i klasztor. Sytuacja zmieniła się dopiero w 1465 r., kiedy gwardianem został Polak, Andrzej Rey. Przy pomocy materialnej synów Macieja Czarnego, którzy darowali klasztorowi dalszy teren, położony wyżej i dalej od rzeki Warty, często dotychczas zalewającej budynki, i z czynnym udziałem biskupa An-

Poloniae Historica"; na język polski przetłumaczył ją Kazimierz Żuchowski OFM i wydał drukiem w 2014 w Wydawnictwie „Calvarianum”. Jan z Komorowa należał do najwybitniejszych bernardynów przełomu XV i XVI stulecia.

${ }^{4}$ Andrzej z Bnina, biskup poznański, ur. ok. 1396, zm. 5 I 1479. Po ukończeniu studiów w Krakowie był sekretarzem królewskim, następnie proboszczem w Pobiedziskach i Międzyrzeczu, kanonikiem łęczyckim i międzyrzeckim, od 1438 biskup poznański, gorliwy pasterz, przeprowadził kilka synodów diecezjalnych, wizytował diecezję, odznaczał się dbałością o wyposażenie kościołów. Zob. P. Nitecki, Biskupi Kościoła w Polsce. Slownik biograficzny, Warszawa 1992, s. 19.

${ }^{5}$ Kroniki bernardynów poznańskich, oprac. S.B. Tomczak, J. Wiesiołowski (dalej cyt. Kroniki), Poznań 2002, s. 3-4. 
drzeja z Bnina rozpoczął budowę nowego murowanego kościoła i klasztoru. Jednak i ten budynek był bardzo skromny. Dopiero w 1470 roku rozpoczęto budowę solidnego kościoła. Budowa trwała trzy lata. Konsekracji dokonał biskup Andrzej z Bnina 25 IV 1473 r., nadając świątyni wezwania: Krzyża Świętego, Wniebowzięcia NMP i Świętych Andrzeja Apostoła, Franciszka z Asyżu i Bernardyna ze Sieny. Była to budowla trzynawowa w stylu późnogotyckim, połączona z klasztorem. Prace wykończeniowe wewnątrz kościoła i klasztoru były prowadzone jeszcze przez kilka lat ${ }^{6}$.

Klasztor poznański pod względem ważności zajmował $\mathrm{w}$ prowincji drugie miejsce po konwencie krakowskim. W 1487 r. został podniesiony do rangi klasztoru kustodialnego, a gwardian otrzymał tytuł kustosza, w związku z czym została poszerzona jego władza na okoliczne klasztory. Do 1800 roku w klasztorze poznańskim odbyło się dwanaście kapituł prowincjalnych. Mieścił się tutaj nowicjat oraz studium teologii, podniesione w 1668 r. do rangi studium generalnego. Z klasztorem poznańskim związanych było wielu wybitnych zakonników, zasłużonych dla Kościoła, zakonu i ojczyzny. Byli to m.in.: św. Jan z Dukli ${ }^{7}$, Jan ze Stopnicy ${ }^{8}$, Jan Szklarek $^{9}$, Innocenty z Kościana ${ }^{10}$, Klemens z Radymna ${ }^{11}$, biskupi sufragani poznańscy: Jakub Dziaduski ${ }^{12}$ i Marian Kurski ${ }^{13}$, artyści malarze i rzeźbiarze:

${ }^{6}$ A. Chadam, Poznań, [w:] Klasztory bernardyńskie w Polsce w jej granicach historycznych, Kalwaria Zebrzydowska 1985, s. 267.

${ }^{7}$ Św. Jan z Dukli, ur. 1414, student Akademii Krakowskiej, wstąpił do Zakonu Braci Mniejszych Konwentualnych, a po kilku latach przeszedł do Braci Mniejszych Obserwantów, czyli bernardynów. Działał w Krakowie, Poznaniu i Lwowie. Jan Paweł II kanonizował go w Krośnie 9 VI 1997.

${ }^{8}$ Jan ze Stopnicy, ur. ok. 1470, profesor Akademii Krakowskiej, komentator dzieł Jana Dunsa Szkota, do Zakonu Braci Mniejszych Obserwantów wstąpił w 1507, wykładał teologię w studium zakonnym w Krakowie i w Poznaniu, gdzie zmarł w 1518.

9 Jan Szklarek, prof. Akademii Krakowskiej, do Zakonu Braci Mniejszych Obserwantów wstąpił w 1476, w Poznaniu pełnił funkcję mistrza nowicjatu i gwardiana. Z tego okresu pochodzi jego rozprawka kanonistyczna pt. De calicibus. Dwukrotnie pełnił funkcję prowincjała. Zmarł w Poznaniu w 1515 w opinii świętości.

${ }^{10}$ Innocenty z Kościana, ur. między 1470-1480, nieznana jest data wstąpienia do zakonu. Był mistrzem nowicjatu, napisał podręcznik dla kształcenia nowicjuszy pt. Manuale noviciorum, gwardian klasztorów w Kościanie, Warszawie i Poznaniu, prowincjał w latach 1534-1537. Brał udział w kapitule generalnej zakonu w Nicei w 1535. Zm. 1541.

${ }^{11}$ Klemens z Radymna, do Zakonu Braci Mniejszych Obserwantów wstąpił ok. 1512, całe życie poświęcił działalności kaznodziejskiej, autor dwóch zbiorów kazań. Zm. w 1562,

12 Jakub Dziaduski, ur. 1490, bernardyn, gwardian poznański, prekonizowany biskupem tytularnym Aenos i sufraganem poznańskim, w 1541 wszedł do kapituły katedralnej. Zm. w 1568.

${ }^{13}$ Maciej Marian Kurski, ur. po 1600, bernardyn, definitor prowincji, w 1650 wybrany przez Jana Kazimierza na biskupa bakowskiego, w 1661 zwolniony z tego biskupstwa z powodu wojen kozackich i mianowany biskupem sufraganem poznańskim, prowadził świątobliwe życie, autor publikacji teologicznych. Zm. w 1681 . 
Hilarion z Poznania ${ }^{14}$, Grzegorz z Wronek ${ }^{15}$, Walenty Żebrowski ${ }^{16}$, Jacek Uzdowski ${ }^{17}$.

Przy kościele istniały, oprócz III Zakonu św. Franciszka, następujące bractwa: św. Anny, Paska św. Franciszka, Świętej Trójcy, Domku Loretańskiego, św. Barbary. W 1480 r. zbudowano kościółek św. Anny, przy którym nie tylko gromadziło się bardzo aktywne bractwo pod jej wezwaniem, ale prowadzone było także duszpasterstwo dla katolików niemieckich.

W czasie najazdu szwedzkiego zakonników zmuszono do opuszczenia klasztoru, który następnie spalono. Zrabowano najcenniejsze przedmioty z zakrystii oraz sporo rękopisów i druków z bogatej biblioteki klasztornej. Do dziś znajdują się one w bibliotekach królewskich w Sztokholmie i Uppsali. Następnie wypalono wnętrze kościoła, podkładając ogień pod ołtarze. Po zakończeniu wojny zakonnicy powrócili do zrujnowanego klasztoru i przy pomocy dobrodziejów i całej prowincji wielkopolskiej zabrali się do odbudowy. Musieli jednak pokonywać wiele przeszkód ze strony rady miejskiej. Ostatecznie jednak odbudowę zakończono w 1668 r. i biskup Maciej Marian Kurski, bernardyn, dokonał poświęcenia, nadając kościołowi tytuł Niepokalanego Poczęcia NMP. Kościół został zbudowany w stylu barokowym według planów włoskich architektów Krzysztofa Bonadury i Jerzego Catenazziego. Złotymi zgłoskami w dziejach klasztoru poznańskiego zapisał się Jan Kapistran Szysiecki ${ }^{18}$, który działał tu przez prawie trzydzieści lat, począwszy od $1712 \mathrm{r}$. $\mathrm{Z}$ jego inicjatywy dokonano gruntownego odnowienia kościoła i klasztoru.

${ }^{14}$ Hilarion z Poznania, data urodzenia nieznana, mensator optimus - stolarz doskonały, uzdolniony rzeźbiarz, mistrz sztuki intarsji, najważniejsze jego dzieło, zachowane do naszych czasów w niezmienionej formie, znajduje się w kościele pobernardyńskim w Sierakowie (Wielkopolska). Są to stalle usytuowane w prezbiterium. Jego dziełem było też wyposażenie zakrystii i stalle w kościele bernardynów w Poznaniu, zniszczone w czasie walk o wyzwolenie miasta spod okupacji niemieckiej. Zm. w 1667 w Poznaniu.

${ }^{15}$ Grzegorz z Wronek, data urodzenia nieznana, był kantorem i kierownikiem chóru zakonnego w znaczniejszych klasztorach bernardyńskich, zwłaszcza w Poznaniu, „nauczycielem śpiewu i pracowitym, nigdy nieodpoczywającym pisarzem ksiąg" - napisano o nim w nekrologu. W 1627 wykonał graduał na pergaminie, który obecnie jest przechowywany w Bibliotece PAN w Kórniku. Zm. 13 X 1639.

${ }^{16}$ Walenty Żebrowski, data urodzenia nieznana, do Zakonu Braci Mniejszych Obserwantów wstąpił w Poznaniu w 1738 jako wyuczony malarz. Malował obrazy w wielu kościołach bernardyńskich: w Poznaniu (nie zachowały się), Wschowie, Warszawie (kościół św. Anny), Łęczycy, Warcie, Kaliszu, Ostrołęce, Skępem.

17 Jacek Uzdowski, żył i działał w tym samym czasie, co Walenty Żebrowski. Malował obrazy i złocił ołtarze w wielu kościołach bernardyńskich. W latach 1719-1737 malował obrazy w kościołach w Świeciu, Lubawie, Grodzisku Wlkp., Górce Klasztornej, Bydgoszczy, Gołańczy i Poznaniu.

${ }^{18}$ Zob. S.B. Tomczak, Jan Kapistran Szysiecki, zastużony bernardyn poznański z przełomu XVII i XVIII stulecia, „Ecclesia. Studia z Dziejów Wielkopolski”, t. 9 (2014), s. 127-152. 
1. Pobernardyński kościół św. Franciszka w Poznaniu przy pl. Bernardyńskim, $1939 \mathrm{r}$

(Wszystkie fotografie zamieszczone w tym artykule pochodzą z Archiwum Klasztoru Franciszkanów w Poznaniu)

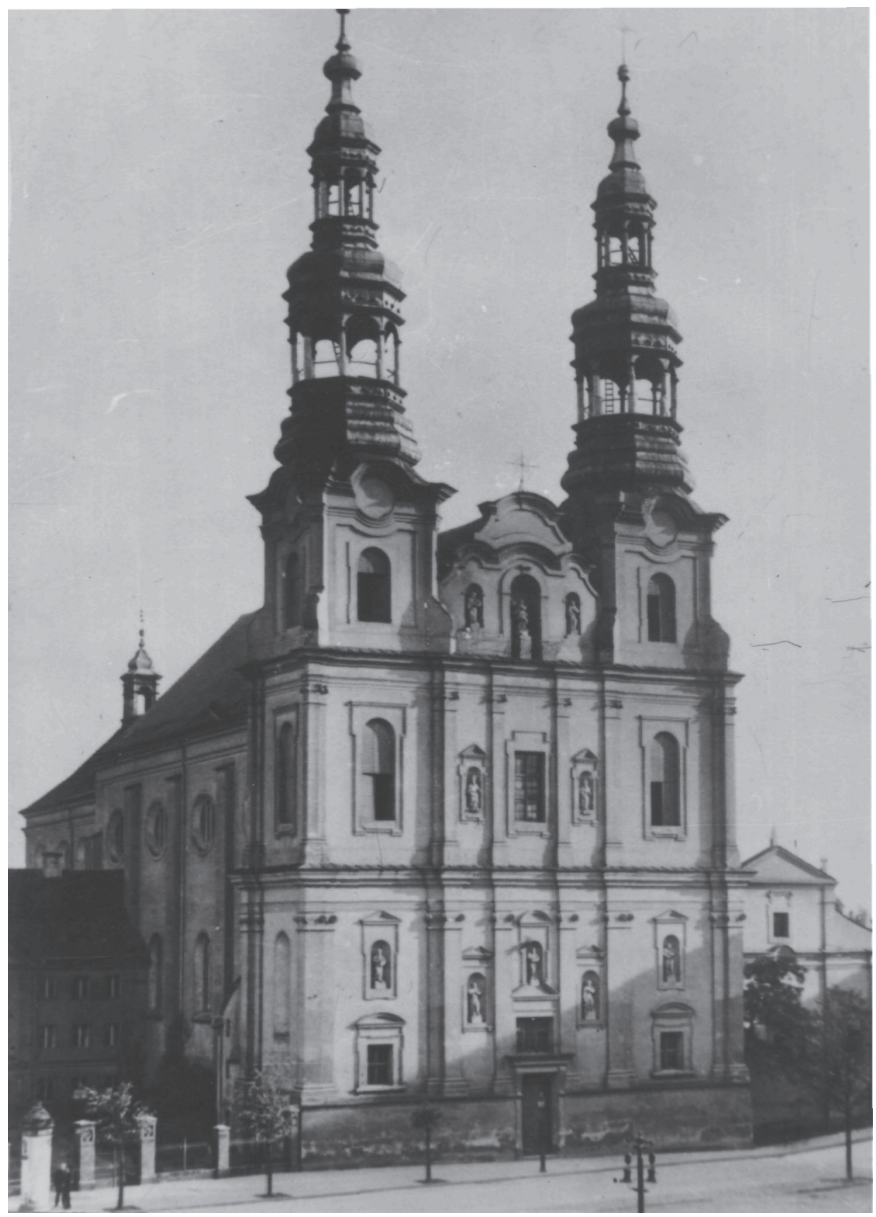

Wybudowano nową fasadę przyozdobioną dwunastoma kamiennymi figurami świętych franciszkańskich oraz dwuprześwitowe hełmy wieżowe, najpiękniejsze w całej Wielkopolsce, w 1750 r. sprawiono do kościoła nowe organy, które zbudował znany śląski organmistrz, Michał Engler Młodszy.

Pruska kasata położyła kres istnieniu klasztoru w 1835 r. Ostatnim zakonnikiem, który zamieszkiwał klasztor, był o. Julian Fujarski, który zmarł w 1841 r. Po jego śmierci kościół i budynki klasztorne zostały przekazane gimnazjum św. Marii Magdaleny.

W czasie II wojny światowej świątynia została zamieniona na warsztaty malarskie dla opery. Bogate wyposażenie wnętrza porąbano i spalono. Reszty dzieła zniszczenia dokonały działania wojenne w 1945 r. Wtedy spaliły się dachy kościoła i klasztoru, wypaliło się wnętrze świątyni, runęły hełmy wieżo- 
we, zniszczeniu uległo sklepienie w prezbiterium i częściowo w nawie głównej. Podobny los spotkał klasztor.

W 1947 r. ruiny kościoła i klasztoru objęli franciszkanie z Prowincji Wniebowzięcia NMP. W 1965 r. kapituła prowincji uchwaliła zlokalizowanie w Poznaniu centralnej biblioteki starodruków i rękopisów. W związku z tym odbudowano północne skrzydło klasztoru. W 1968 r. rozpoczęło się zwożenie starodruków i rękopisów z prowincji. W ten sposób w Poznaniu znalazło się ok. 8000 starodruków, wśród nich 144 inkunabuły (druki XV-wieczne). Od 1978 r. przy klasztorze istnieje muzeum, w którym zgromadzono wiele dzieł sztuki (obrazy, rzeźby, eksponaty misyjne).

W 1983 r. zakończono prace nad rekonstrukcją hełmów wieżowych i dachu na kościele. Ponadto zrekonstruowano sklepienie w prezbiterium, wykonano sztukaterie na sklepieniu nawy głównej, dwa boczne ołtarze, nowy ołtarz ustawiony według wskazań soboru watykańskiego II, zakupiono cztery żyrandole, cały kościół pomalowano. Klasztor pokryto blachą miedzianą. W latach 1986-1987 zbudowano dom przeznaczony na mieszkanie dla sióstr Franciszkanek od Pokuty i Miłości Chrześcijańskiej, które wykonywały prace na rzecz klasztoru. W klasztorze mieści się redakcja rocznika naukowego pt. „Studia Franciszkańskie” (wydano 28 tomów) i seria wydawnicza pt. „Biblioteka Studiów Franciszkańskich" (wydano 22 tomy).

Przy kościele istnieje parafia. Ojcowie obsługują Wojewódzkie Centrum Onkologiczne przy ul. Garbary. W kościele czczona jest łaskami słynąca figura Matki Bożej Loretańskiej oraz krzyż z XVII/XVIII w. w krypcie kościoła.

\section{Starania o odzyskanie kościoła i klasztoru pobernardyńskiego w Poznaniu}

Franciszkanie z Prowincji Wniebowzięcia NMP z siedzibą prowincjała w Katowicach Panewnikach, którzy na terenie Wielkopolski i Kujaw mieli kilka klasztorów (Wronki, Miejska Górka, Osieczna, Kobylin, Pakość), podejmowali próby odzyskania kościoła i klasztoru pobernardyńskiego w Poznaniu już w okresie dwudziestolecia międzywojennego - niestety bezskutecznie. Również ludzie świeccy upominali się o zwrot tego kościoła prawowitym właścicielom, czyli duchowym synom św. Franciszka z Asyżu. Potwierdza to interesujący wycinek prasowy z „Kuriera Poznańskiego” (niestety nie odnotowano numeru i roku), przechowywany w zasobach archiwalnych klasztoru. Oto jego treść: 


\section{Ratujmy piękny zabytek sztuki - kościół Bernardyński! Kiedy wrócą OO. Bernardyni?}

Piszą nam z miasta:

Piętnaście już lat minęło od chwili, gdy Polska wyzwolona ze szpon hydry „trzygłowej” gospodarzy w własnem ognisku. Piętnaście już lat roztacza biały Orzeł swe skrzydła nad polską ziemią i powiewa nad nią sztandar Królowej Korony Polskiej. Powrócili na rodzinną glebę z radosnem sercem wygnańcy - tułacze z dalekich krajów i z za morza do swych strzech i pałaców. Powrócili też z brzękiem rozkołysanych dzwonów wolności wygnani okrutną żelazną ręką barbarzyńskiego Prusaka - zakonnicy do swych klasztorów i kościołów. Każdy czuje się szczęśliwy, swobodny we własnem polskiem ognisku. W Poznaniu objęli swój kościół OO. Konwentualni, w Polsce [znani] jako Franciszkanie. Powrócili OO. Jezuici, objąwszy kościół Podominikański. Działalność swą rozpoczęli Ks. Ks. Salezjanie w spróchniałych ruinach kościoła Katarzynek. Nie należy pominąć OO. Zmartwychwstańców i Karmelitanki Bose, którzy wybudowali Poznaniowi dwa kościoły!

Wymienieni z niezmordowaną, nadludzką siłą zabrali się do pracy. OO. Franciszkanie odnowili przy pomocy całego, znanego z ofiarności swej, społeczeństwa poznańskiego kościół swój pod wezwaniem Św. Antoniego przy ul. Ludgardy. OO. Jezuici odnowili kościół Podominikański, fundując nawet nowe organy. Na szczególne uznanie zasługują Ks. Ks. Salezjanie, którzy objąwszy zgrzybiałą, cuchnącą ruderę kościoła Katarzynek (kościół ten zamieniono w wieku dziewiętnastym na wojskowy magazyn i stajnię dla koni), uczynili z niego miły przybytek Pański.

Cześć wszystkim pionierom Pańskim!

U OO. Franciszkanów kwitnie podupadły w czasach zaborczych III. Zakon. Setki tysięcy głodnych otrzymuje stale kilka razy w tygodniu chleb zwany „Chlebem św. Antoniego".

OO. Zmartwychwstańcy kierują parafją wildecką, obejmująca 30 tyś. dusz.

Ciche, korne modlitwy zamkniętych w heroicznem zaparciu siebie, za kratą, w dobrowolnem więzieniu Karmelitanek Bosych, ustawicznie płyną jak kadzidło do Boga.

Ks. Ks. Salezjanie na szczytnem stanowisku pedagogicznem, działając dobrym przykładem i zrozumieniem młodocianych dusz, wychowują je z wielkim mozołem i trudnościami materjalnemi.

Tylko dawni właściciele poważnej bardzo placówki w Poznaniu nie powrócili jeszcze do „swego". To są ci, których zakon już w wieku szesnastym słynął w Polsce z działalności, zakon, który wydał dużo polskich świętych. Zakon pierwszy niezreformowany, zachowujący jeszcze ostrą pierwszą regułę swojego założyciela św. Franciszka z Asyżu. - Są to OO. Franciszkanie-Bernardyni. Czeka na nich społeczeństwo poznańskie, krzyczą o pomoc popękane klęską powodzi 


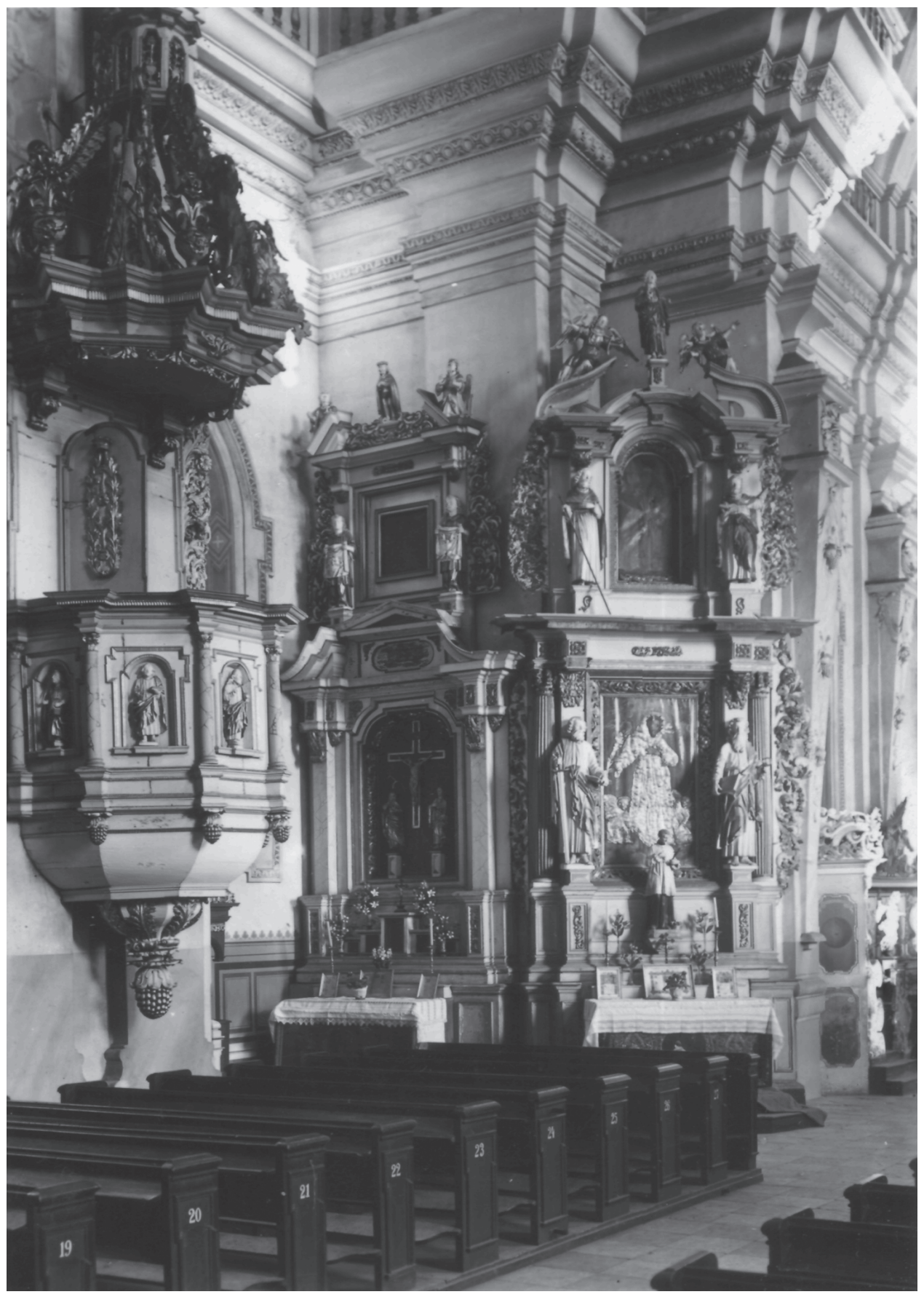

2. Widok na ambonę i boczne ołtarze, 1939 r. Fot. R.S. Ulatowski 
mury i fundamenty kościoła Bernardynów, domagają się renowacji sklepienia, posadzki, ołtarze.

Osierocony kościół Bernardynów stoi smutny, w grobowej ciszy - zapomniany. Dlaczego nie otwierają się podwoje tej wspaniałej świątyni miasta Poznania? Głucho i ciemno jak w zborze luterskim - raz tylko w niedzielę otwiera się kościół dla młodzieży gimnazjalnej. Gdzie są właściciele i gospodarze tego kościoła, który powstał z ich rąk, myśli i serca, a w którego podziemiach spoczywają zwłoki ich braci zakonnych. Dlaczego nie powrócili dotąd, by stanąć wśród szeregu wybitnych swych poprzedników, by dorównać im w pracy i wskrzeszeniu z letargu kościoła do nich należącego?

N. N.

Można powiedzieć, że po II wojnie światowej sytuacja się w pewnym sensie odwróciła. To władze państwowe zwróciły się do franciszkanów z propozycją objęcia ruin kościoła i klasztoru pobernardyńskiego i jego odbudowy. W styczniu 1947 r. o. Antoni M. Galikowski ${ }^{19}$, prowincjał Prowincji Wniebowzięcia NMP, otrzymał pismo z Urzędu Wojewódzkiego w Poznaniu z propozycją nawiązania rozmów w sprawie rewindykacji pobernardyńskiego zespołu kościelno-klasztornego w Poznaniu. Odpowiedź była pozytywna. Dla przeprowadzenia wszelkich pertraktacji w tej sprawie zarząd prowincji wydelegował o. Romualda Warzechę ${ }^{20}$. Wkrótce okazało się jednak, że placówka jest własnością Państwa Polskiego, pod zarządem Kuratorium Poznańskiego. Trzeba było wykazać, że obiekt należy do zakonu, nigdy nie został sprzedany, lecz uległ niesprawiedliwej konfiskacie podczas zaboru pruskiego. Potrzebne materiały dowodowe znalazły się w Archiwum Archidiecezjalnym² ${ }^{21}$.

Sprawą rewindykacji zajmował się oddział Prokuratury Generalnej w Poznaniu, który wstępnie przyznał placówkę zakonowi, ale ostateczne rozstrzygnięcie uzależnił od Prokuratury w Warszawie, ta zaś po długich debatach zawyrokowała, że sprawę rewindykacji obiektów sakralnych skonfiskowanych

${ }^{19}$ Wincenty Galikowski, imię zakonne Antoni Maria, ur. 1879, do Zakonu Braci Mniejszych w Prowincji Niepokalanego Poczęcia NMP w Wielkim Księstwie Poznańskim i Prusach Zachodnich wstąpił w 1904, pierwsze śluby zakonne złożył w 1905, śluby uroczyste w 1910, święcenia kapłańskie przyjął w 1910. Studia specjalistyczne z zakresu filozofii odbył w Berlinie, Wrocławiu i ukończył w Poznaniu, uzyskując w 1921 tytuł doktora. W latach 1926-1929 w Instytucie Archeologii Chrześcijańskiej w Rzymie odbył studia specjalistyczne, uwieńczone stopniem doktora teologii. Był profesorem w studium zakonnym we Wronkach, kustoszem prowincji (1932-1935), definitorem (1935-1938) i prowincjałem (1938-1950). Zm. w 1950.

${ }^{20}$ Antoni Warzecha, imię zakonne Romuald, ur. 1912, do Zakonu Braci Mniejszych w Prowincji Wniebowzięcia NMP wstąpił w 1930, pierwsze śluby zakonne złożył w 1931, profesję uroczystą w 1934, święcenia kapłańskie przyjął w 1937. W latach 1947-1950 i 1956-1962 był definitorem prowincji. Zm. w 1964.

21 Archiwum Klasztoru Braci Mniejszych w Poznaniu (dalej: AKP), Kronika Klasztoru OO. Franciszkanów w Poznaniu, maszynopis (dalej: Kronika), s. 1. 
podczas zaborów na podstawie konkordatu rozstrzygać winna tzw. Komisja Mieszana (Rządu i Episkopatu), a z braku tejże Sejm. Żeby jednak można było przystąpić do ratowania zniszczonego zabytku, zaproponowała długoterminową dzierżawę na dziewięćdziesiąt dziewięć lat w wysokości symbolicznej złotówki. Na podstawie nowej uchwały zaproponowano własność na trzydzieści lat. Formalności zostały załatwione w Warszawie, a odpowiednie pismo otrzymały władze wojewódzkie ${ }^{22}$.

Jako uzupełnienie tych informacji dołączam dwa dokumenty i świadectwa ojców: Leona Wojsyka i Juliana Lewandowicza (zachowano oryginalną pisownię).

Pierwszy dokument:

Tłumaczenie $\mathrm{z}$ tekstu łacińskiego

Przewielebny Ojcze,

List Twój z dnia 26 lutego, w którym prosisz o pozwolenie, mocą którego mogłaby ta prowincja odzyskać dla siebie kościoły i klasztory dawnej prowincji OO. Bernardynów, przedłożyłem memu Najprzewielebniejszemu Definitorium do rozpatrzenia, aby wypowiedziało w tej sprawie swoje zdanie.

$\mathrm{Na}$ wczorajszym więc posiedzeniu, które odbyło się wieczorem, Najprzewielebniejsze Definitorium wypowiedziało się, że ze swej strony nie ma nic przeciwko temu, abyś podjął się sprawy powyższego odzyskania, byle tylko domy, o których tu mowa, były nabyte dla Zakonu lub Prowincji i na korzyść i użytek naszych Braci.

Gdy orzeczenie Definitorium Tobie donoszę z racji mego urzędu, udzielam Tobie zarazem i Twoim poddanym serafickiego błogosławieństwa $z$ całego serca i pozostaję z serafickim pozdrowieniem.

Tobie w Panu oddany

/-/ Br. Bonawentura Marrani, z Zakonu Braci Mniejszych

Za zgodność z oryginałem

Generał

Panewnik, dnia 22 stycznia $1947 \mathrm{r}$.

o. Antoni M. Galikowski Prowincjał

${ }^{22}$ AKP, Kronika, s. 1; AKP, Zapiski do kroniki klasztornej o. Romualda Warzechy, rękopis bez sygnatury, s. 1. 


\section{Drugi dokument:}

$\underline{\text { Odpis }}$

\section{Do}

Najprzewielebniejszego Prowincjałatu Braci Mniejszych Prowincji Niepokalanego Poczęcia N.P.Marji w Panewniku na Górnym Śląsku.

Definitorjum Prowincji Niepokalanego Poczęcia N. Marji Panny w Małopolsce na rocznym Kongresie Definitorialnym w Rzeszowie, dnia 28 sierpnia 1923. uchwaliło - co następuje: „Klasztory nasze w Wielkopolsce oddaje się naszym Braciom na Górnym Śląsku”.

Lwów, dnia 26 października 1929.

L.S.

$$
\begin{gathered}
\text { /-/ O. Benedykt Wiercioch } \\
\text { prowincjał }
\end{gathered}
$$

Z polecenia N.O. Prowincjała

O. Oton Zugaj

Sekretarz Prowincji

Za zgodność z oryginałem

Panewnik, dnia 22 stycznia 1947 r.

\section{o. Antoni M. Galikowski \\ Prowincjał}

\section{Świadectwo o. Leona Wojsyka ${ }^{23}$}

Gdy 12 kwietnia 1945 r. w drodze do Wronek (na 3 tygodnie zastępstwa, trwające potem 3 1/2 roku!) chodziłem po gruzach kościoła i klasztoru w Pozna-

${ }^{23}$ Józef Wojsyk, imię zakonne Leon, ur. w 1916, do Zakonu Braci Mniejszych w Prowincji Wniebowzięcia NMP wstąpił w 1932, pierwsze śluby zakonne złożył w 1933, śluby uroczyste w 1937, święcenia kapłańskie przyjął w 1939. Po wojnie, jako człowieka uzdolnionego muzycznie, przełożeni skierowali na studia w Akademii Muzycznej w Poznaniu, gdzie studiował kilka lat, ale studiów nie ukończył z powodu wielkiego zapotrzebowania na duszpasterzy. Był wychowawcą i nauczycielem młodzieży zakonnej w klasztorach w Nysie, Osiecznej i Jarocinie, przełożonym w kilku klasztorach (Wronki, Wschowa, Pakość). Przez kilka lat pracował w Austrii. Zm. w Katowicach Panewnikach w 2010. 
niu, miałem poważne wątpliwości, czy uda nam się odbudować ten wspaniały zabytek. Władze prowincji zadecydowały jednak i sprawy podjął się o. Romuald Warzecha.

Był już chyba rok 1946 (lub 1947?), gdy o. Antoni Galikowski, prowincjał, polecił mi pomoc ojcu Romualdowi w staraniach o odzyskanie klasztoru („,Ojciec studiował w Poznaniu, ma tam znajomość i tedy może pomóc ojcu Romualdowi...").

Poszliśmy wpierw do oo. Karmelitów. Na gruzach ich klasztoru spotkaliśmy ojca Przeora. „Proszę udać się na Plac Wolności. W gmachu PKO, na 7 czy 8 piętrze urzęduje Generalny Prokurator, on wam powie, co trzeba robić, by klasztor odzyskać".

Pan Prokurator bardzo się ucieszył: „Kamień z głowy i serca! Dobrze, że ojcowie zajmiecie się zabytkiem, zaoszczędzicie Państwu wydatków”. Dodał chyba jeszcze, że Państwo zajmie się w pierwszej kolejności odbudową urzędów i szkół...

Polecił nam też udać się do Konserwatora wojewódzkiego oraz do Miejskiego Komitetu Odbudowy na Jeżycach w sprawie ewentualnej pomocy. Poszliśmy od razu na Jeżyce i zastaliśmy Komitet Odbudowy Poznania przy naradzie. Przewodniczący, inż. Ciesielski (Cieśliński?) bardzo się ucieszył z naszego oświadczenia przejęcia klasztoru i obiecał pomoc. O ile wiem, dostaliśmy 35 tysięcy zł. na odbudowę Kaplicy Loretańskiej. Byłem też u Konserwatora Wojewódzkiego, prof. Kostrzewskiego. Poparł nasze zamiary. Innym razem zastępca Konserwatora wojew., pani Ruszczyńska wyjęła z szuflady 2 pisma i zapytała: „Ojcowie z której Prowincji, ojca Szepelaka, czy Galikowskiego? - Oczywiście: Galikowskiego. To dobrze, odrzekła. Proszę dostarczyć odpisy wszelkich dokumentów, dotyczących waszego klasztoru".

W myśl poprzednich zaleceń Prokuratora Gen. o. Romuald parę tygodni spędził w Archiwum Archidiecezji Poznańskiej, odpisując i fotografując wszelkie dokumenty dotyczące klasztoru i kościoła.

$* * * * * * * * * * * * *$

Przeniesiony z początkiem września 1948 do Wschowy, a po roku do Nysy, straciłem bezpośredni kontakt z klasztorem w Poznaniu. Wróciłem doń jako wikary domu w lipcu 1952, po likwidacji naszego Seminarium w Jarocinie. Mieszkaliśmy jeszcze ciągle pod kaplicą Loretańską. Przenosiny do odbudowanego skrzydła [klasztoru] nastąpiły 25 września 1952. W urządzeniu domu finansowo i „ręcznie” bardzo nam pomogli Państwo Krajewiczowie (pl. Bernardyński 1). O. Ireneusz Kmiecik, ówczesny proboszcz w Kuźnicy na Helu, rzekł do o. Romualda: „Odprawię wam 30 intencji, skreślcie je sobie, boście tu dobrą robotę zrobili”.

o. Leon [Wojsyk] 


\section{Wspomnienia O. Juliana Floriana Lewandowicza ${ }^{24}$ (starania i zabiegania o klasztor Franciszkanów w Poznaniu przy placu Bernardyńskim)}

Był rok 1939. W czasie wakacji z okazji świąt wielkanocnych przyjechałem tu na urlop, spędzając go na zastępstwie u Sióstr Urszulanek w Pokrzywnie. Właśnie tu otrzymałem telefon od O. Prowincjała Antoniego Galikowskiego, który poprosił mnie, abym stawił się w określonym terminie i towarzyszył mu w złożeniu wizyty Prymasowi Polski - A. Hlondowi, zabiegając oczywiście o ten klasztor. I byliśmy. Widziałem, że kardynał Hlond miał 101 różnych wymówek, żeby tego klasztoru nam nie dać. Po wyjściu od kardynała, O. Prowincjał Galikowski stwierdził, że on szykuje to dla salezjanów, ale ze łzami w oczach oświadczył: Ale Pan Bóg sprawi, że będzie to nasze.

Potrzeba jednak było wojny i gruzów... Ale i te gruzy zdobyć było bardzo ciężko. Mianowicie tu do Poznania przyjechałem z Krakowa poprzez Ostrów (gdzie mam siostrę) i byłem po jurysdykcję u biskupa Dymka, bo on został w czasie wojny cały czas tu w Poznaniu, podtrzymywał naród poznański na duchu, a urzędował przy kościele Matki Boskiej na Łazarzu. Jurysdykcję otrzymałem, ale przy okazji poprosiłem biskupa Dymka, żeby nam przekazał te gruzy Kościoła bernardyńskiego. Usłyszałem odpowiedź: Proszę Ojca - ja nie jestem ordynariuszem, bo jeszcze Hlond nie zrezygnowat z urzędu. Ta odpowiedź mi starczyła, bo wiedziałem, że gdy nim zostanie to otrzymamy. I tak było...

Poszedłem do Kurii w roku następnym, tj. w 1946. Kanclerzem był Ks. Haendschke pochodzący tak jak ja z Koźmina, nasze rodziny były dosyć zżyte z sobą. Poprosiłem o ten klasztor. Biskup Dymek oświadczył, że w tej sprawie zglasza się tu wielu zakonników, nawet ze Lwowa, Krakowa, że ja nie wiem kogo to właściwie jest.

Poradziłem, by pytać przychodzących, czy macie klasztor we Wronkach, gdyż klasztor ten należy do nas Franciszkanów. (W 1937 roku otrzymaliśmy tam święcenia kapłańskie - 18 nas było. Pamiętam, że na pożegnanie Ks. Biskupa po święceniach zagraliśmy „Marsz gladiatorów”. Nawiązał do tych gladiatorów, przewidywał wojnę i ciekawą mowę powiedział).

Ten argument przemówił, wszystkie prośby zostały odrzucone. Biskup poinformował, że państwo będzie ubezpieczało mury klasztoru i kościoła, wszystkie

${ }^{24}$ Florian Lewandowicz, imię zakonne Julian, ur. 1912, do Zakonu Braci Mniejszych w Prowincji Wniebowzięcia NMP wstąpił w 1933, pierwsze śluby zakonne złożył w 1934, śluby uroczyste w 1937, święcenia kapłańskie otrzymał w 1937, od 1938 studiował na Akademii Sztuk Pięknych w Krakowie. Niestety studia przerwała wojna, ale dokończył je po zakończeniu okupacji. Jednym z jego mistrzów był Zbigniew Pronaszko. Malował ludzi (portrety), pejzaże gór, ruch uliczny. Stosował technikę olejną, akwarelową, gwasz, pastel i rysunek. Uprawiał głównie malarstwo sztalugowe, ale nie stronił od sztuki ściennej. Oprócz polichromii kaplicy Loretańskiej w Poznaniu malował także w Kalwarii Pakoskiej k. Inowrocławia, gdzie był przez pewien czas przełożonym. W 1973 zaprojektował kolorystykę kościoła franciszkanów w Poznaniu, powtórzoną w 1983 w czasie kolejnego malowania świątyni. Zm. w Poznaniu 1997. 
zabytki, a więc może dopiero realizacja będzie możliwa w przysztym roku. Prowincjat jednak powinien napisać ponowna prośbę i uzasadnienie, gdyż decyzja ta nie zależy tylko od biskupa, ale również od Kapituły i dopiero po wystuchaniu jej głosu może podjąć ostateczną decyzję.

Wyjechałem do Krakowa, tam skończyłem Akademię [Sztuk Pięknych]. Przyjechałem do Panewnika, gdzie O. Prowincjał poinformował mnie, że mamy Poznań i ty tam pójdziesz na przełożonego. Niestety nie mogłem tego przyjąć ze względu na ciężką żółtaczkę z perspektywą leżenia w szpitalu do pół roku. I tak też było.

Kiedy wróciłem w styczniu do Panewnika, nalegałem na Prowincjała, żeby posłał tam kogoś, gdyż dom ten wymagał bardzo wiele trudu, by go pozyskać, mianowicie takim protektorem był (poza innymi znajomościami) brat biskupa Dymka: Leon Dymek. On był moim dyrektorem w Seminarium Nauczycielskim, a ja byłem na najlepszej pozycji i dlatego jako ksiądz już przed wojną składałem mu wizyty i on też się dużo przyczynił do tego, że klasztor odzyskaliśmy.

Prowincjał prosił mnie, bym kogoś zaproponował. Moim kandydatem był tylko o. Romuald. Uargumentowałem pytanie o. Prowincjała: dlaczego o. Romuald? W moim odczuciu o. Romuald miał smykałkę, w Rybniku stary kościółek przerobił na piękne salki, robotnicy przychodzili do pomocy bezpłatnie. Widziałem u niego zmysł praktyczny. Według mnie on się nadawał. I tak zostało.

O. Prowincjał zwołał posiedzenie definitorium, na którym O. Romuald został zamianowany przełożonym Poznania. Potem, pamiętam, O. Romuald przyszedł mi serdecznie podziękować za kandydaturę, bo cieszył się, że będzie przełożonym w Poznaniu.

Taki był początek klasztoru w Poznaniu...

Odbudowa zaczęła się od piwnic pod kaplicą loretańską. Ja przyszedłem do Poznania trochę później, gdyż musiałem po chorobie wydobrzeć. Radziłem też w wielu rzeczach, np. żeby ołtarz z tabernakulum i aniołów postawić w tym miejscu, gdyż taki był styl Capellacciego, że ołtarz był wysunięty i tak były kościoły bernardyńskie budowane (a zwiedziłem wszystkie kościoły bernardyńskie). Ja to znałem, gdyż u nich byłem na stancji w czasie studiów.

Wspomnienie spisano w Poznaniu w Uroczystość Zesłania Ducha św. 4 czerwca a.d. 1995 .

\section{Odbudowa pobernardyńskiego zespołu kościelno-klasztornego w Poznaniu}

Pierwsi franciszkanie z Prowincji Wniebowzięcia NMP, którzy przybyli do Poznania, aby się podjąć trudu odbudowy zniszczonego obiektu, od lutego 1947 do maja 1948 r. mieszkali u sióstr elżbietanek przy ul. Łąkowej. Później udało się pozyskać mieszkanie przy ul. Mickiewicza 30. Składało się ono z czterech pokoi, łazienki i kuchni. Jeden z pokoi zamieniono na kaplicę, gdzie 
odprawiano mszę św. i zbierano się na wspólne modlitwy. Pierwszą wspólnotę tworzyli: o. Romuald Warzecha - przełożony, o. Lucjan Klepek ${ }^{25}$ i br. Jacek Podlewski ${ }^{26}$. W lipcu przybył br. Mainrad Wieczorek ${ }^{27}$ z bratniej Prowincji św. Jadwigi na Śląsku, doświadczony budowniczy, który objął funkcję inspektora nadzoru budowlanego.

Franciszek Jaśkowiak, zasłużony dla inwentaryzacji szkód, jakie Niemcy wyrządzili zabytkom Poznania, tak pisał: „Z kościołów poznańskich, obok kościoła św. Marcina, ostatnia wojna najokrutniej dotknęła kościół pobernardyński [...]. Podczas oblężenia Poznania Niemcy z kościoła zrobili redutę, ostrzeliwując się z dział i wypuszczając z tego miejsca pociski przeciwpancerne, zwane „pancerfaust”, na czołgi rosyjskie. Stąd kościół ten był specjalnym celem artylerii rosyjskiej. Dziw, że całkowicie nie legł w gruzach. Dumne jego wieżyce, zakończone przeźroczystymi hełmami o dwóch kondygnacjach, górujące dawniej nad miastem, strawił pożar. Pod murami kościoła leży przepalona i powyginana blacha ze spalonych hełmów. $Z$ wież pozostały trzy dolne kondygnacje. Dolna część wieży południowej szczególnie silnie ucierpiała. [...] Zachodnia ściana kaplicy loretańskiej silnie uszkodzona. Ściany południowa i północna nie wykazują większych uszkodzeń, miejscami odpadłe tynki odsłoniły cegłę [...]. Wnętrze wypalone zupełnie, a posadzka zasłana popiołami. Bogate jego dekoracje, pochodzące z połowy wieku 18, przepadły prawie zupełnie. $Z$ malowideł pozostały tylko fragmenty na sklepieniu nawy i na stropie zakrystii, z hojnie rozrzuconych ozdób stiukowych tylko nieliczne uszkodzone tutti, rozety i ornament roślinny [...]. Sklepienie prezbiterium runęło. $\mathrm{Z}$ dawnego klasztoru bernardynów ocalał tylko parter; pierwsze i drugie piętro zupełnie zniszczone" 28 .

${ }^{25}$ Henryk Kleppek, imię zakonne Lucjan, ur. 1914, do Zakonu Braci Mniejszych w Prowincji Wniebowzięcia NMP wstąpił w 1933, święcenia kapłańskie przyjął w 1940, w 1956 został inkardynowany do ordynariatu gorzowskiego. Zm. w 1957.

${ }^{26}$ Franciszek Podlewski, imię zakonne Jacek, ur. 1904, do Zakonu Braci Mniejszych w Prowincji Wniebowzięcia NMP wstąpił w 1930, pierwsze śluby zakonne złożył w 1932, a śluby uroczyste w 1935. W prowincji pełnił różne funkcje. Był głównie kucharzem i zakrystianem, ale także ogrodnikiem i kwestarzem. Od 1958 przez kilka lat był zakrystianem i przewodnikiem dla pielgrzymów polskich i niemieckich w bazylice Matki Boskiej Anielskiej w Asyżu. Od 1962 pracował w Kustodii Ziemi Świętej, najdłużej w Jaffie. Zm. w 1973.

${ }^{27}$ Ludwik Wieczorek, imię zakonne Mainrad, ur. w 1883, do Zakonu Braci Mniejszych w Prowincji św. Jadwigi wstąpił w 1912, pierwsze śluby zakonne złożył w 1913, śluby wieczyste (uroczyste) w 1919. Jako wyuczony murarz, swoje umiejętności budowlane doskonalił pod okiem br. Mansweta Fromma OFM, architekta. Br. Mainrad prowadził budowy w Panewnikach, Borkach Wielkich (furta), Nysie (sala gimnastyczna i stajnie), Gliwicach (przebudowa klasztoru), Berlinie Pankow, Dusznikach Zdroju, Wrocławiu (drukarnia i Dom Związkowy), Kłodzko (remont kapitalny). Pewne prace budowlane prowadził także w Rzymie i na Sycylii. Zm. w Raciborzu w 1966 i tam został pochowany.

${ }^{28}$ Cyt. za: J. Figuła-Czech, D. Leśniewska, Odbudowa i rekonstrukcja kościoła i klasztoru OO. Bernardynów, „Kronika Miasta Poznania”, 2005, nr 2, s. 108. 


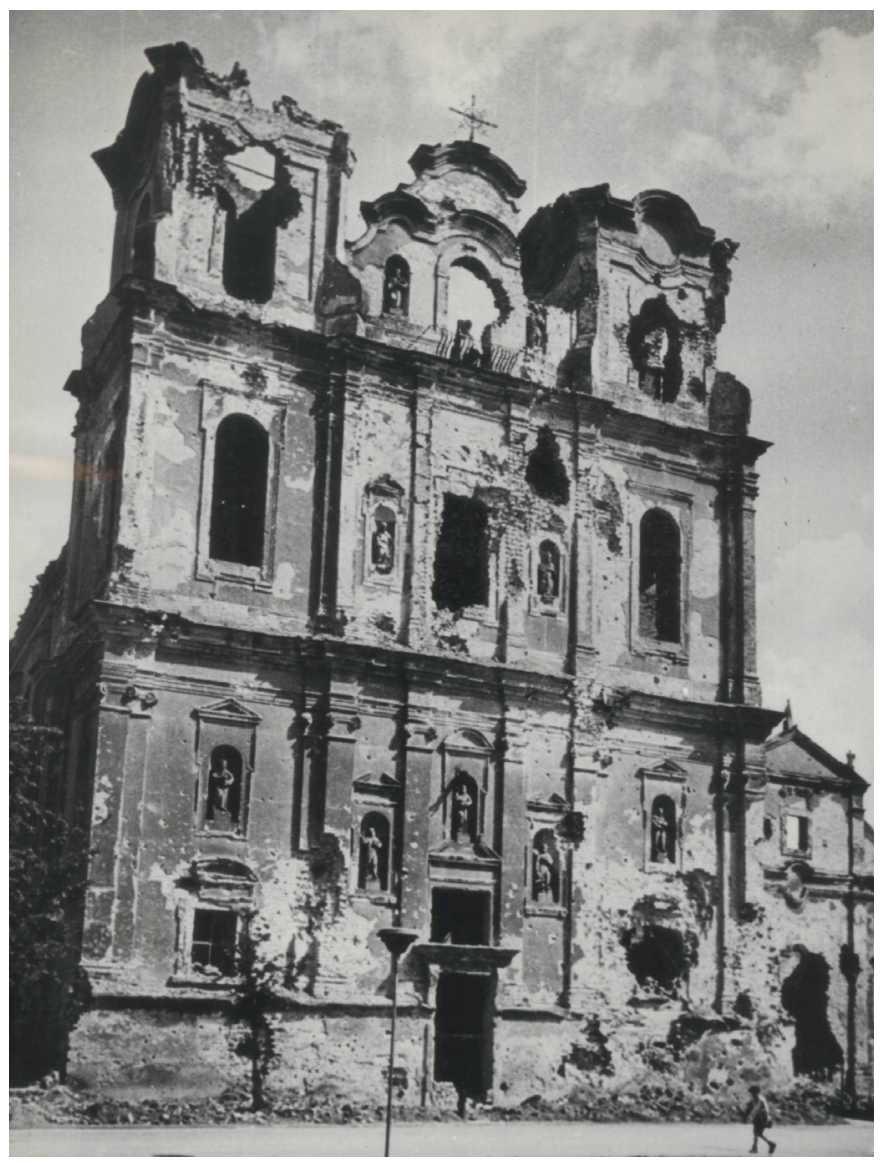

3. Fasada kościoła zniszczona w czasie walk na początku 1945 r. Fot. R.S. Ulatowski

\section{Odbudowa kaplicy Matki Bożej Loretańskiej}

Odbudowę zespołu kościelno-klasztornego rozpoczęto od kaplicy Matki Bożej Loretańskiej. Na teren ruin kaplicy weszli zakonnicy w lipcu 1948 r., ale prace zaczęły się na dobre dopiero 2 sierpnia, w symboliczną uroczystość Matki Bożej Anielskiej z Porcjunkuli, kolebki zakonu franciszkańskiego.

Obraz zniszczeń kaplicy ukazują przytoczone niżej dane:

kubatura: $960 \mathrm{~m}^{3}$, zniszczenia: $75 \%$,

kubatura zniszczeń: $750 \mathrm{~m}^{3}$, wartość zniszczeń: 92880 zł².

${ }^{29}$ Raport o stratach wojennych Poznania 1939-1945, red. A. Sakson, A. Skarzyński, Poznań 2008, s. 69. 
4. Fresk na sklepieniu kaplicy Matki Bożej Loretańskiej, $1953 \mathrm{r}$.

Fot. Laskowski

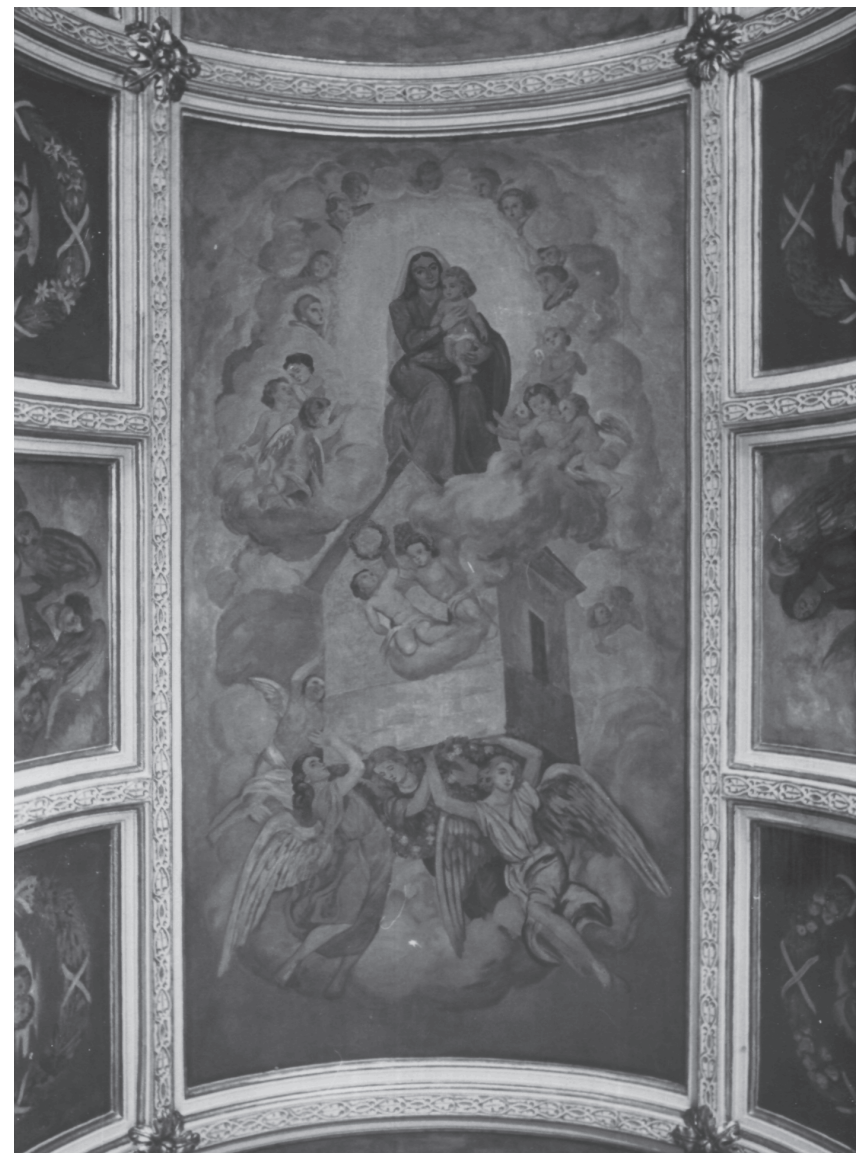

Zniszczona kaplica robiła porażające wrażenie. Przytoczone wyżej dane liczbowe nie oddają w pełni rzeczywistego stanu. Lepiej ukazują to załączone do artykułu zdjęcia dokumentalne. W kronice klasztornej zapisano, że dach był spalony, zerwane sklepienie, również sklepienia krużganków mocno nadwyrężone, sklepienia między kaplicą a podziemiem częściowo zapadnięte, ściana frontowa rozbita przez bomby. Usuwaniem gruzów i oczyszczeniem ścian zajęli się robotnicy z firmy Szmyd. W pierwszej kolejności nad kaplicą ułożono dach kryty dachówką. Wewnątrz kaplicy i w krużgankach, które ją okalają, wykonano sklepienie beczkowe. Na podstawie zdjęć z Loreto zbudowano ołtarz. Do kaplicy wchodziło się przez główne wejście do kościoła, z tym że drewniane schody zamieniono na betonowe. Drzwi do kościoła wykonano $\mathrm{z}$ drewna dębowego. W krużgankach zainstalowano centralne ogrzewanie i podłączono je do pomieszczeń podziemnych, gdzie zostało urządzone 
tymczasowe mieszkanie dla zakonników, którzy przenieśli się z ul. Mickiewicza. Wejście prowadziło z ul. Raczyńskich, obecnie ul. Garbary ${ }^{30}$.

Kaplica Matki Bożej Loretańskiej była ulubionym miejscem modlitwy mieszkańców Poznania, w związku z czym była w centrum zainteresowania gospodarzy tego miejsca, którzy starali się ją ciągle upiększać. W 1953 r. ukończono budowę ołtarza, kaplicę wymalowano, na sklepieniu pojawiły się obrazy pędzla artysty malarza o. Juliana Lewandowicza OFM i jego kolegi ze studiów, prof. Zdzisława Przebindowskiego ${ }^{31}$ z Krakowa, nawiązujące do historii Domku Loretańskiego. Otwarcie odnowionej kaplicy nastąpiło 28 października 1953 roku $^{32}$.

\section{Odbudowa kościoła}

Odbudowa kościoła rozpoczęła się 2 V 1949 r. Stan zniszczenia ukazują poniższe dane:

kubatura: $31880 \mathrm{~m}^{3}$,

zniszczenia: $75 \%$,

kubatura zniszczeń: $23910 \mathrm{~m}^{3}$,

wartość zniszczeń wyceniono na $4088610 \mathrm{zt}^{33}$.

Prace przy odbudowie kościoła rozpoczęły się od nawy głównej z łukiem tęczowym i nawy bocznej. Były one niezwykle trudne. Najpierw trzeba było zgromadzić materiał na rusztowania. Tutaj wielce pomocnym okazał się dar o. Solana Ratajczyka, gwardiana klasztoru w Kobylinie, który przysłał wagon drągów na rusztowanie. Poważny problem stanowiło sklepienie. Państwowa komisja budowlana dwukrotnie orzekła, że sklepienie powinno być rozebrane i zbudowane nowe. Po długich naradach i dyskusjach zdecydowano się jed-

${ }^{30}$ AKP, Kronika, s. 2.

31 Zdzisław Przebindowski, ur. 1902, artysta malarz, w 1920 podjął naukę w poznańskiej Szkole Sztuk Zdobniczych i Przemysłu Artystycznego, w 1925 powrócił do Krakowa, gdzie studiował na Akademii Sztuk Pięknych (pracownia F. Pautscha). Po skończeniu studiów osiadł na jakiś czas w Paryżu. Następnie mieszkał i pracował kolejno w Wenecji, Florencji i Rzymie. Na przełomie 1937 i 1938 powrócił do Krakowa i podjął pracę pedagogiczną na ASP, którą przerwała II wojna światowa. Na uczelnię wrócił w roku 1945, pracował na niej do 1972 roku. Malował pejzaże, sceny rodzajowe, martwe natury, portrety. Działał w licznych organizacjach i towarzystwach (m.in. w Towarzystwie „Sztuka”, Towarzystwie Sztuk Pięknych, Związku Polskich Artystów Plastyków). Odznaczony Krzyżem Kawalerskim Orderu Odrodzenia Polski. Jego prace znajdują się m.in. w Muzeum Narodowym w Krakowie, Muzeum Narodowym w Poznaniu, Muzeum Śląska Opolskiego, Muzeum w Grudziądzu, w kolekcjach prywatnych. W 1996 roku nazwano jego imieniem jedną z ulic w Krakowie. Zm. w 1986.

${ }^{32}$ AKP, Kronika, s. 8-9.

${ }^{33}$ Raport o stratach wojennych Poznania, s. 69. 


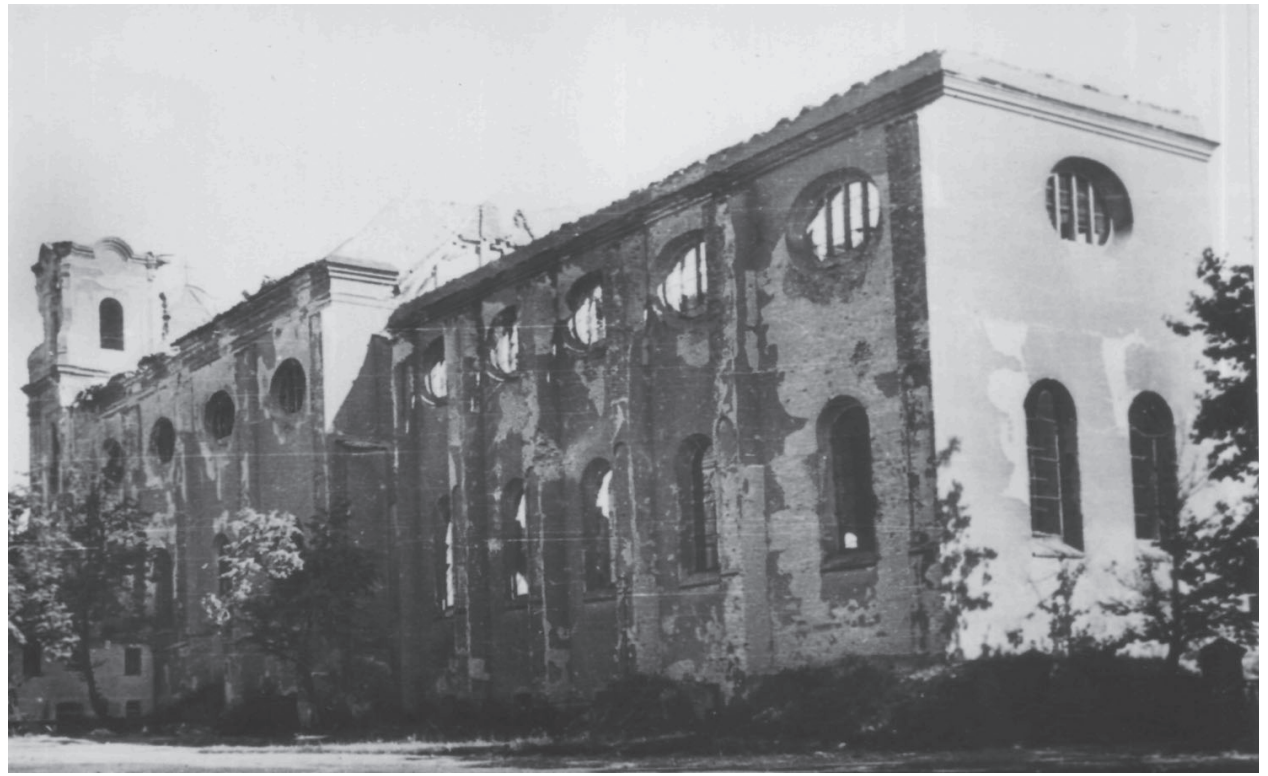

5. Kościół od strony południowo-wschodniej, 1945 r. Fot. R.S. Ulatowski

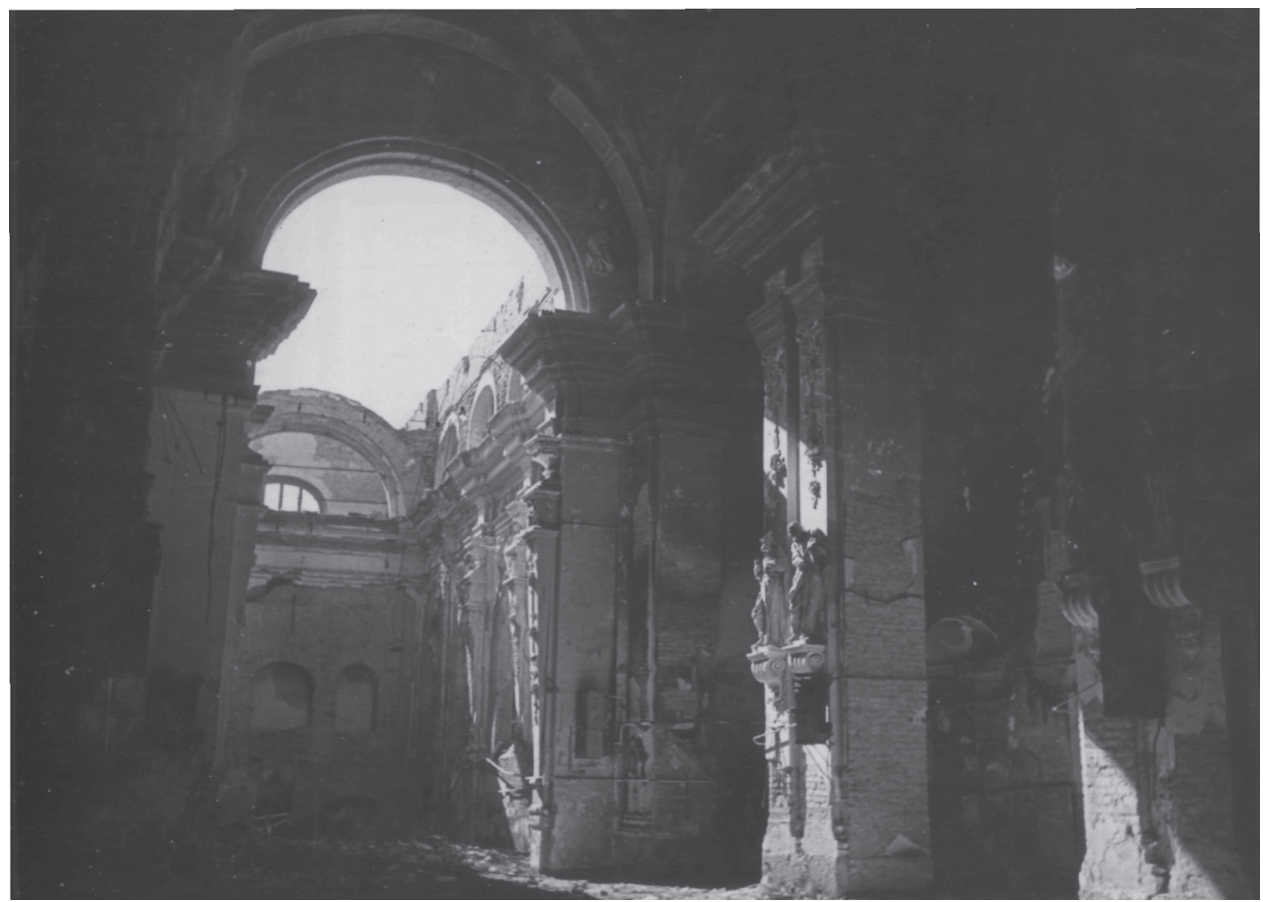

6. Widok wnętrza kościoła w kierunku wschodnim, 1945 r. Fot. R.S. Ulatowski 
nak na rekonstrukcję sklepienia bez rozbiórki uszkodzonego. Pozostawało ono w tragicznym stanie. Cegła w połowie była zmurszała, gurty poodpadały, sklepienie w kilku miejscach było poprzebijane przez pociski i bomby. Wykorzystano stare nadwątlone sklepienie dla podtrzymania nowego. Robotnicy wbijali w trzęsące się nieraz sklepienie haki i klamry, wszystko to połączyli gęsto drutem i narzucili pierwszą warstwę betonu. Do wystających haków i klamer przyczepili drugi raz drut, tak że tworzył gęstą siatkę, na to nałożono drugą warstwę betonu i otynkowano. Cel został osiągnięty. Sklepienie razem z narzuconymi warstwami betonu utworzyło mocną całość i w ten sposób zostało uratowane ${ }^{34}$.

Po zakończeniu prac ratujących sklepienie przystąpiono do odtwarzania gzymsów wzdłuż kościoła. Plastyczne ornamentacje odtwarzano razem z tynkowaniem. Nie są one nalepiane, lecz rzeźbione w masie. Pracy tej podjął się plastyk z Poznania, Józef Pade ${ }^{35}$ razem z br. Leonardem Bannertem ${ }^{36}$ z Prowincji św. Jadwigi, podobnie jak wspomniany już br. Mainrad Wieczorek. Zrekonstruowali oni również figury dwunastu apostołów na pilastrach, balustradę na chórze organowym oraz ambonę. Przed wojną ambona była umieszczona na pierwszym filarze w nawie głównej, teraz znalazła miejsce na ścianie łuku tęczowego. Po wykonaniu tych prac kościół został pomalowany, ułożono cementową posadzkę i zrobiono część ławek z drewna dębowego - boki wyrzeźbił br. Leonard Bannert ${ }^{37}$.

Dnia 8 grudnia 1949 r., w uroczystość Niepokalanego Poczęcia NMP, Królowej Zakonu Serafickiego, biskup pomocniczy poznański Franciszek Jedwabski ${ }^{38}$ dokonał poświęcenia nawy głównej do łuku tęczowego oraz naw bocznych. Następnie celebrował uroczystą sumę w asyście kleryków seminarium poznańskiego i wygłosił kazanie. Śpiewy gregoriańskie wykonał chór kleryków. Natomiast po południu uroczyste nieszpory odprawił o. prowincjał

\footnotetext{
${ }^{34}$ AKP, Kronika, s. 3.

${ }^{35}$ Autorowi artykułu nie udało się znaleźć żadnych informacji na temat tego artysty.

${ }^{36}$ Franciszek Bannert, imię zakonne Leonard, ur. w 1901, do Zakonu Braci Mniejszych w Prowincji św. Jadwigi wstąpił w 1927, pierwsze śluby zakonne złożył w 1928, śluby wieczyste (uroczyste) w 1931. Był zdolnym rzeźbiarzem. Sztuki rzeźbiarskiej uczył się w Szkole Snycerstwa profesora Cyrilla Dell'Antonio w Cieplicach Śląskich k. Jeleniej Góry. Jego prace rzeźbiarskie znajdują się w kilku klasztorach Prowincji św. Jadwigi, szczególnie na Górze św. Anny. W Poznaniu są następujące jego dzieła: św. Jakub Starszy, św. Jakub Młodszy, św. Andrzej, św. Franciszek, św. Jan Kapistran, sarkofag Matki Bożej i Jej Wniebowzięcie jako pendant do ambony, sześć starych podniszczonych figur w prezbiterium, głośniki, komplet siedzeń przy tronach (dwa fotele, sześć taboretów), płaskorzeźby w stallach w prezbiterium oraz na górnych gzymsach wokół prezbiterium. Zm. w 1970 na Górze św. Anny i tam został pochowany.

${ }^{37}$ AKP, Kronika, s. 3.

${ }^{38}$ Franciszek Jedwabski, ur. 1895, święcenia kapłańskie przyjął w 1922, sufraganem poznańskim mianowany w 1946. Zm. w 1975.
} 
7. Fragment wnętrza kościoła, $1945 \mathrm{r}$. Fot. R.S. Ulatowski

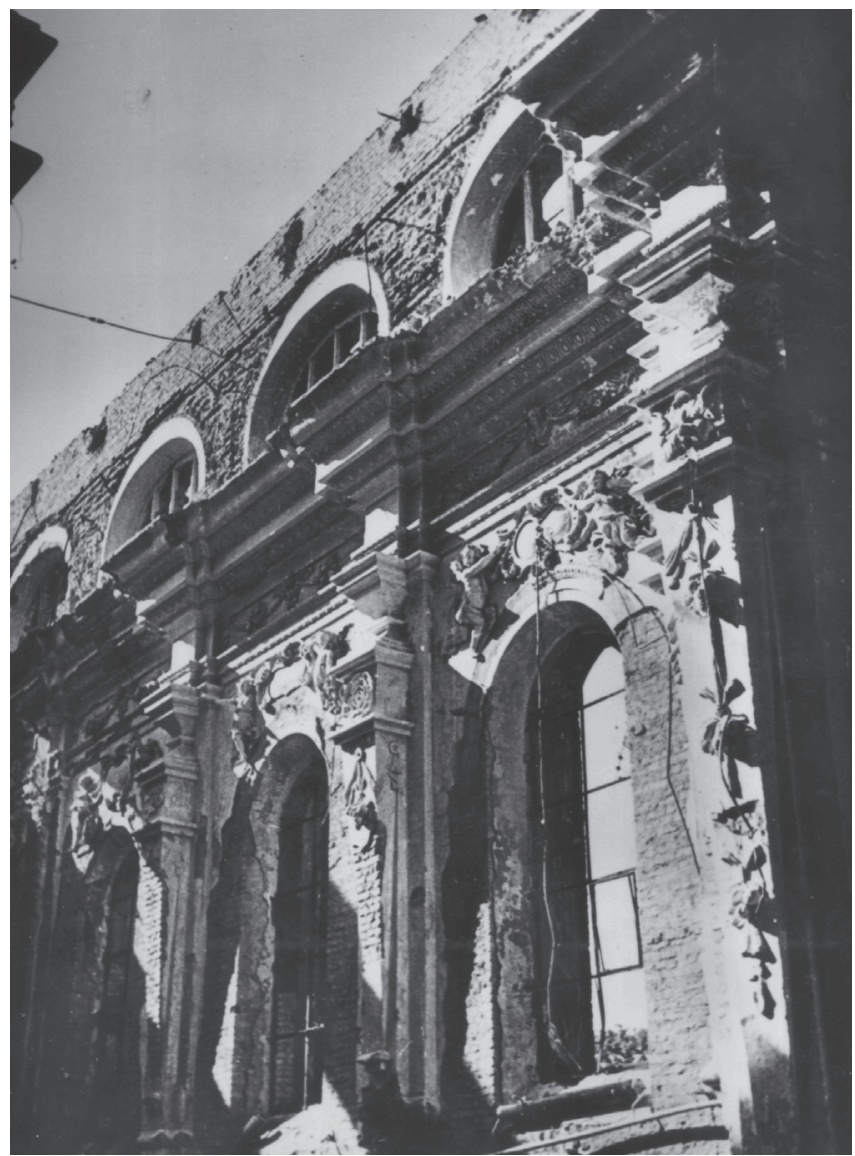

Antoni Galikowski, a kazanie wygłosił o. Norbert Chudoba ${ }^{39}$, proboszcz parafii przyklasztornej w Katowicach Panewnikach. Podczas nieszporów śpiewał chór ks. Gieburowskiego pod dyrekcją Stefana Stuligrosza ${ }^{40}$.

W 1950 r. rozpoczął się trzeci etap odbudowy kościoła i objął głównie prezbiterium, którego sklepienie było całkowicie zniszczone. Najważniejsze

39 Walenty Chudoba, imię zakonne Norbert, ur. w 1908, do Zakonu Braci Mniejszych w Prowincji Wniebowzięcia NMP wstąpił w 1924, pierwsze śluby zakonne złożył w 1925, śluby uroczyste w 1929, święcenia kapłańskie przyjął w 1932, w niższym seminarium duchownym w Kobylinie uczył języka polskiego, przez rok był rektorem tej szkoły, w 1937 rozpoczął studia w Wyższej Szkole Dziennikarskiej w Warszawie, w czasie wojny pracował w parafii przyklasztornej w Rybniku, po wojnie został proboszczem parafii w Katowicach Panewnikach, gdzie m.in. zainicjował budowę stacji różańcowych na Kalwarii Panewnickiej, szerzył kult Matki Bożej Fatimskiej, zm. w 1965 w Wiedniu w drodze powrotnej z pielgrzymki do Ziemi Świętej.

${ }^{40}$ AKP, Kronika, s. 4. 
i zarazem najtrudniejsze prace przy rekonstrukcji sklepienia wykonali bracia zakonni Hubert Rosenthal ${ }^{41}$ i Jan Piernikarczyk ${ }^{42}$. Zrealizowali oni konstrukcję drewnianą, obili trzciną, a murarze otynkowali ${ }^{43}$.

Po zakończeniu tych robót zajęto się głównym ołtarzem. Nastawa ołtarza została umieszczona na tylnej ścianie prezbiterium. Część górną wykonano z drewna, następnie obciągnięto ją siatką drucianą i otynkowano. Dół, poniżej kolumn, jest murowany i również otynkowany. W środku umieszczono obraz św. Franciszka z Asyżu, „obrońcy świata”. Jest to kopia obrazu Rubensa, którą wykonał artysta malarz, Józef Pade z Poznania. Sam ołtarz główny z dwoma mensami i tabernakulum pancernym umieszczono w połowie prezbiterium. Tabernakulum, które wykonała firma Kosickiego z Poznania, wewnątrz wyłożono złoconą blachą. Obudowę drewnianą oraz figury dwóch aniołów trzymających wieczne lampki wykonał rzeźbiarz Franciszek Masorz z Rybnika. W prezbiterium zrekonstruowano stalle. Płaskorzeźby przedstawiające sceny z życia św. Franciszka wykonał br. Leonard Bannert na podstawie przedwojennych zdjęć znanego poznańskiego fotografika dokumentalisty, Romana Stefana Ulatowskiego ${ }^{44}$. Po obu stronach prezbiterium znajdują się dwa trony: po stronie Ewangelii, czyli po prawej stronie, umieszczono godło papieża Piusa XII, ponad tronem aniołowie trzymają tarczę z godłem zakonu franciszkańskiego, czyli dwie skrzyżowane ręce, Chrystusa i św. Franciszka z Asyżu. Po stronie Lekcji znajduje się godło metropolity poznańskiego ks. abpa Walentego Dymka. Nad tym z kolei tronem aniołowie podtrzymują herb miasta Poznania $^{45}$.

${ }^{41}$ Karol Rosenthal, imię zakonne Hubert, ur. 1882, do Zakonu Braci Mniejszych w Saksońskiej Prowincji pw. Krzyża Świętego wstąpił w 1910, pierwsze śluby zakonne złożył w 1911, śluby uroczyste w 1920. Jako wyuczony stolarz i cieśla pracował przy budowie lub rozbudowie klasztorów w Holandii i Niemczech. W 1924 przeszedł do Prowincji Wniebowzięcia NMP w Polsce. Przed wojną pracował przy budowie kolegium serafickiego w Jarocinie, a po wojnie przez kilka lat przy odbudowie kościoła i klasztoru w Poznaniu i Opolu. Zm. w Opolu w 1971.

${ }^{42}$ Paweł Piernikarczyk, imię zakonne Jan, do Zakonu Braci Mniejszych w Prowincji Wniebowzięcia NMP wstąpił w 1953, pierwsze śluby złożył w 1954, śluby uroczyste w 1956, w latach 1953-1984 przebywał w klasztorze poznańskim, gdzie pracował przy odbudowie kościoła i klasztoru. Bez najmniejszej przesady można powiedzieć, że prawie każdy element drewniany (okna, drzwi, podłogi, meble, wyposażenie zakrystii, kaplicy zakonnej itp.) przeszedł przez jego ręce. Zm. w Opolu w 2000 .

${ }^{43}$ AKP, Kronika, s. 4.

${ }^{44}$ Roman Stefan Ulatowski, fotografik, redaktor i działacz społeczny, ur. 1881, naukę w zakładzie fotograficznym E. Mirskiej w Poznaniu rozpoczął w 1895, swoje umiejętności doskonalił w Dreźnie, Monachium i Berlinie. W 1914 w Poznaniu otworzył własny zakład fotograficzny, od 1923 redagował miesięcznik ,Światłocień, pierwsze polskie czasopismo poświęcone fotografii zawodowej. W latach dwudziestych ub. stulecia rozpoczął systematyczne fotografowanie najcenniejszych zabytków Poznania i Wielkopolski. Po wojnie zorganizował pracownię fotograficzną przy Zarządzie Miejskim. Pracował nad dokumentowaniem zniszczeń Poznania. Zm. w 1959 w Poznaniu.

${ }^{45}$ AKP, Kronika, s. 5. 
8. Nowy obraz w głównym ołtarzu, $1953 \mathrm{r}$.

Fot. Laskowski

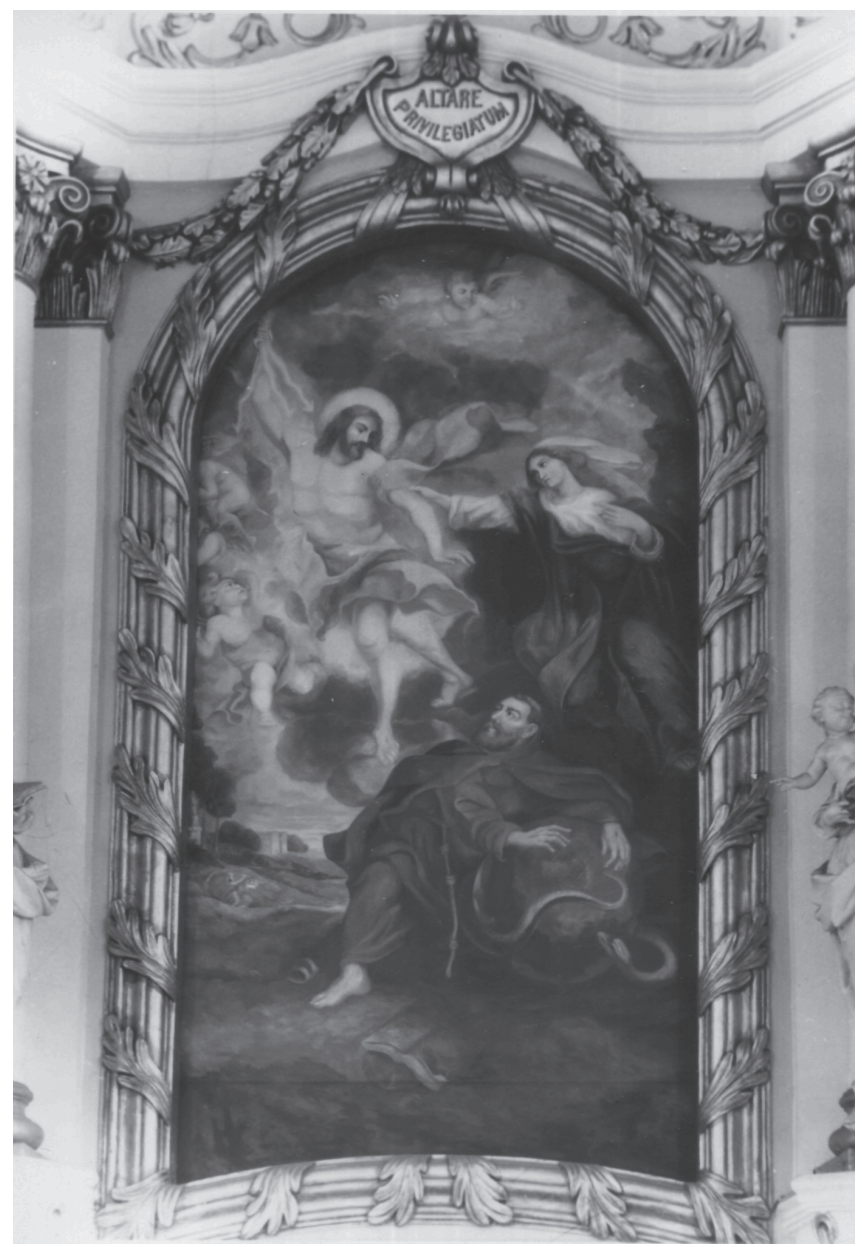

Prace remontowe w prezbiterium ukończono we wrześniu 1951 r. W uroczystość św. Franciszka z Asyżu, założyciela zakonu i patrona kościoła, odbyła się konsekracja głównego ołtarza, której dokonał ks. arcybiskup poznański Walenty Dymek ${ }^{46}$. Metropolita przybył do kościoła o godz. 11. Po ceremonii konsekracji ołtarza sumę odpustową odprawił nowy prowincjał o. Tytus

${ }^{46}$ Walenty Dymek, ur. 1888, święcenia kapłańskie przyjął w 1912, był wikariuszem w Ostrzeszowie, profesorem seminarium duchownego, kanonikiem poznańskim, działaczem chrześcijańsko-społecznym, biskupem sufraganem poznańskim mianowany w 1929, mimo internowania w czasie okupacji niemieckiej sprawował rządy w archidiecezji, w 1946 został mianowany arcybiskupem poznańskim. Przyczynił się do odbudowy życia religijnego po II wojnie światowej, dzięki jego zabiegom i staraniom odbudowano katedrę i seminarium duchowne, spełniał funkcje biskupie w diecezjach pozbawionych biskupów. Zm. w 1956. 
Semkło $^{47}$, a arcybiskup uczestniczył w niej z tronu biskupiego. Kazanie odpustowe wygłosił gwardian klasztoru we Wronkach, o. Władysław Gawlik ${ }^{48}$.

W tych samych latach po lewej stronie kościoła dobudowano część klasztoru, w którym urządzono zakrystię, a nad nią oratorium, czyli chór zakonny. Przed wojną zakrystia znajdowała się za głównym ołtarzem ${ }^{49}$.

Po zakończeniu prac w kaplicy Matki Bożej Loretańskiej front pracy przesunął się znowu do kościoła, który był pomalowany tylko prowizorycznie i domagał się ostatecznego wykończenia. Tego zadania podjął się br. Izydor Wójciak $^{50}$. Świątynia została pomalowana na biało, ozdoby plastyczne wyzłocono. Firma Szott położyła w kościele posadzkę. Z powodu braku prawdziwego marmuru położono płyty ze sztucznego marmuru tzw. „lastrico-marmur”. Później się okazało, że było to wielkie oszustwo. Płyty się łuszczyły i były źródłem nieustannego kurzu w kościele. Do ostatecznego wykończenia potrzebne było jeszcze ogrzewanie kościoła. Po długich dyskusjach zdecydowano się na ogrzewanie nawiewne, zainstalowane pod kościołem tuż przy kaplicy Matki Bożej Loretańskiej. Piec wykonała firma Piotra Materzoka z Zawady na Śląsku ${ }^{51}$.

W III niedzielę po Zesłaniu Ducha Świętego 1956 r. została otwarta i poświęcona krypta - kaplica Świętego Krzyża, usytuowana tuż przy wejściu do kościoła. Umieszczono tam konfesjonały do stałego dyżuru spowiedniczego, żeby wierni mieli bliżej z ulicy i by w spowiedzi nie przeszkadzała gra organów ${ }^{52}$.

Równocześnie rozpoczęto stawiać rusztowanie przy fasadzie kościoła od strony placu Bernardyńskiego, aby otynkować wieże. W celu przyśpieszenia

${ }^{47}$ Stanisław Semkło, imię zakonne Tytus, ur. w 1911, do Zakonu Braci Mniejszych w Prowincji Wniebowzięcia NMP wstąpił w 1930, pierwsze śluby zakonne złożył w 1931, śluby uroczyste w 1934, święcenia kapłańskie otrzymał w 1937. W czasie wojny ukrywał się, po wojnie przez krótki czas był gwardianem w Osiecznej, następnie we Wschowie, w 1950 został mianowany prowincjałem, w latach 1968-1974 był gwardianem w Poznaniu, a w latach 1977-1983 gwardianem w Katowicach Panewnikach. Zm. w 1999.

${ }^{48}$ Jan Gawlik, imię zakonne Władysław, ur. 1901, do Zakonu Braci Mniejszych w Prowincji Wniebowzięcia NMP wstąpił w 1922, pierwsze śluby zakonne złożył w 1923, śluby uroczyste w 1926, święcenia kapłańskie otrzymał w 1928, w 1956 przeszedł do Prowincji św. Jadwigi. Zm. w 1963.

${ }^{49}$ AKP, Kronika, s. 6.

${ }^{50}$ Bolesław Wójciak, imię zakonne Izydor, ur. w 1916, do Zakonu Braci Mniejszych w Prowincji Wniebowzięcia NMP wstąpił w 1938, pierwsze śluby zakonne złożył w 1939, śluby uroczyste w 1947. Miał zdolności malarskie i dekoratorskie. Przebywał w kilku klasztorach, najdłużej w Poznaniu, gdzie przez szereg lat budował w kościele żłóbek na Boże Narodzenie i namalował kilka obrazów, które do dzisiaj zdobią ściany klasztoru. Zm. w 1971, pochowany został na cmentarzu przyklasztornym w Osiecznej k. Leszna.

${ }^{51}$ AKP, Kronika, s. 10.

${ }^{52}$ Tamże, s. 11. 
tych prac o. gwardian Idzi Tic ${ }^{53}$ wysunął myśl utworzenia koła sympatyków kościoła św. Franciszka spośród byłych uczniów gimnazjum św. Marii Magdaleny i gimnazjum Bergera, którzy uczęszczali do tego kościoła jako szkolnego. Myśl tę poparło wielu znakomitych obywateli miasta oraz duchownych. Dnia 13 maja zapoczątkowano akcję wysyłania „,cegiełek” na odbudowę wież kościoła ${ }^{54}$.

\section{Odbudowa klasztoru}

Najważniejsze prace w kościele zakończono w 1952 r. W tej sytuacji można było przystąpić do odbudowy klasztoru, a ściślej mówiąc tej jego części, która przylegała do kościoła. Stan zniszczonego budynku klasztornego ukazują poniższe dane:

kubatura: $12110 \mathrm{~m}^{3}$,

zniszczenia: $75 \%$,

kubatura zniszczeń: $9082 \mathrm{~m}^{3}$,

wartość zniszczeń: 1171642 zł $^{55}$.

Prace budowlane postępowały szybko. W suterynie odbudowanej części klasztoru urządzono trzy pokoje mieszkalne i kuchnię, na parterze zlokalizowano furtę klasztorną, pokój gościnny zwany „prowincjałówką”, na pierwszym piętrze znalazła się jedna cela zakonna i mieszkanie przełożonego, czyli gwardianat, salka rekreacyjna i sanitariaty ${ }^{56}$.

${ }^{53}$ Paweł Tic, imię zakonne Idzi, ur. 1914, do Zakonu Braci Mniejszych w Prowincji Wniebowzięcia NMP wstąpił w 1932, pierwsze śluby zakonne złożył w 1933, śluby wieczyste (uroczyste) w 1936, święcenia kapłańskie przyjął w 1939, w czasie II wojny światowej był więźniem obozu koncentracyjnego w Buchenwaldzie i Dachau (1940-1945), po powrocie do prowincji pełnił wiele odpowiedzialnych funkcji: był przełożonym klasztorów w Jarocinie, Wejherowie, Poznaniu, definitorem prowincji, wychowawcą młodzieży zakonnej, proboszczem, wikarym klasztoru, prowincjalnym moderatorem duszpasterstwa misyjno-rekolekcyjnego, ponadto był wizytatorem generalnym Prowincji Niepokalanego Poczęcia NMP, Matki Boskiej Anielskiej i św. Jadwigi Zakonu Braci Mniejszych w Polsce, w latach 1972-1979 pracował w sekretariacie generalnym zakonu w Rzymie, w 1973 brał udział w kapitule generalnej w Madrycie jako ekspert do spraw redakcji konstytucji generalnych, w latach 1980-1984 był gwardianem klasztoru i proboszczem w St. Pölten w Austrii, od 1984 przebywał w Bensheim jako gwardian. Z powodu pogarszającego się stanu zdrowia w 1989 powrócił do prowincji i osiadł na stałe w klasztorze panewnickim. Zm. 21 stycznia 1994. W 1990 otrzymał Krzyż Zasługi I Klasy Orderu Zasługi Republiki Federalnej Niemiec, przyznany przez prezydenta Niemiec Weizsäckera za zasługi dla pojednania Polaków i Niemców. Krzyż został uroczyście wręczony 11 lipca 1990 w ambasadzie Republiki Federalnej Niemiec w Warszawie. Jest autorem książki pt. Przez Dachau do Rzymu, Poznań 1971, i kilku artykułów, które opublikował na łamach „Przewodnika Katolickiego” i „Miesięcznika Kościelnego Archidiecezji Poznańskiej”.

${ }^{54}$ AKP, Kronika, s. 14.

${ }^{55}$ Raport o stratach wojennych Poznania, s. 71.

${ }^{56}$ AKP, Kronika, s. 8. 
Praca nad odbudową nie ustawała. Aby powiększyć mieszkanie dla ojców i braci, zaczęto odbudowywać skrzydło północne klasztoru. Nowa część klasztoru została oddana do użytku $25 \mathrm{~V} 1952$ roku $^{57}$.

W lutym 1957 r. monterzy z Orzesza na Śląsku zaczęli zakładać instalację telefoniczną w klasztorze. Objęła ona poddasze, gdzie mieszkali bracia zakonni, chór, zakrystię, „pogotowie spowiedziowe”, cele ojców, furtiana, kuchnię oraz część klasztoru, która była jeszcze w odbudowie, tj. część północną, gdzie miał się znaleźć gwardianat, salka rekreacyjna, refektarz i pokoje gościnne. Do instalacji użyto 300 m.b. kabla, składającego się z 60 żył ${ }^{58}$.

\section{Organy i dzwony}

Kościół bernardynów poznańskich znany był przed II wojną światową z okazałych organów. Niestety ten trzydziestopięciogłosowy instrument, największy w Wielkopolsce, o niepowtarzalnym brzmieniu, zbudowany przez śląskiego organmistrza Michała Englera Młodszego ${ }^{59}$, spłonął w 1945 r. $^{60}$ Ponieważ trudno sobie wyobrazić tak wspaniałą świątynię, jak kościół św. Franciszka w Poznaniu, bez organów, podjęto starania o ich uzyskanie. Pod koniec 1952 r. odkupiono od Urzędu Likwidacyjnego zniszczone w 60\% organy ze zburzonego kościoła protestanckiego w Zbąszyniu. Był to instrument wykonany w firmie Gebrüder Walther z Guhrau (Górowo na Śląsku). Naprawę zlecono firmie organmistrzowskiej Władysława Kaczmarka z Wronek, który brakujące głosy uzupełnił piszczałkami z innych rozebranych instrumentów. Zainstalowane na chórze organy zostały poświęcone 3 maja 1953 r. przed sumą przez prowincjała o. Tytusa Semkło. Okolicznościowe kazanie wygłosił o. Idzi Tic z Jarocina, który w znacznym stopniu przyczynił się do pozyskania tego instrumentu. Podczas uroczystości śpiewał chór pod dyrekcją Stefana Stuligrosza ${ }^{61}$.

${ }^{57}$ Tamże.

58 Tamże, s. 14.

${ }^{59}$ Michał Engler, ur. w 1688 we Wrocławiu, tam kształcił się w prestiżowym gimnazjum św. Elżbiety. Sztuki organmistrzowskiej nauczył się od rodzonego ojca i stryja, a doskonalił w Saksonii u mistrza Gottfrieda Silbermanna. Samodzielną pracę rozpoczął w wieku 32 lat. Pierwsze organy, które zbudował samodzielnie w Oleśnicy, były wielkim sukcesem. Później zbudował organy m.in. w Brzegu (kościół św. Mikołaja), cystersów w Krzeszowie, Ołomuńcu (Morawy), Wrocławiu (kościół św. Elżbiety), a także w Międzyborzu, Młodoszowicach, Kuraszkowie, Wielowsi, Oławie, Psarach, Piotrkowiczkach, Trzebnicy, Święciechowej k. Leszna Wlkp., dla bernardynów w Poznaniu, Kościanie i Łęczycy. W 1733 r. zbudował organy w kościele dominikanów w Poznaniu. Zm. w 1760.

${ }^{60}$ Zob. M.P. Czechlewski, Wielkie organy Michała Englera Młodszego w kościele bernardynów w Poznaniu, ,Studia Franciszkańskie”, 18 (2008), s. 317-327.

${ }^{61}$ AKP, Kronika, s. 8. 


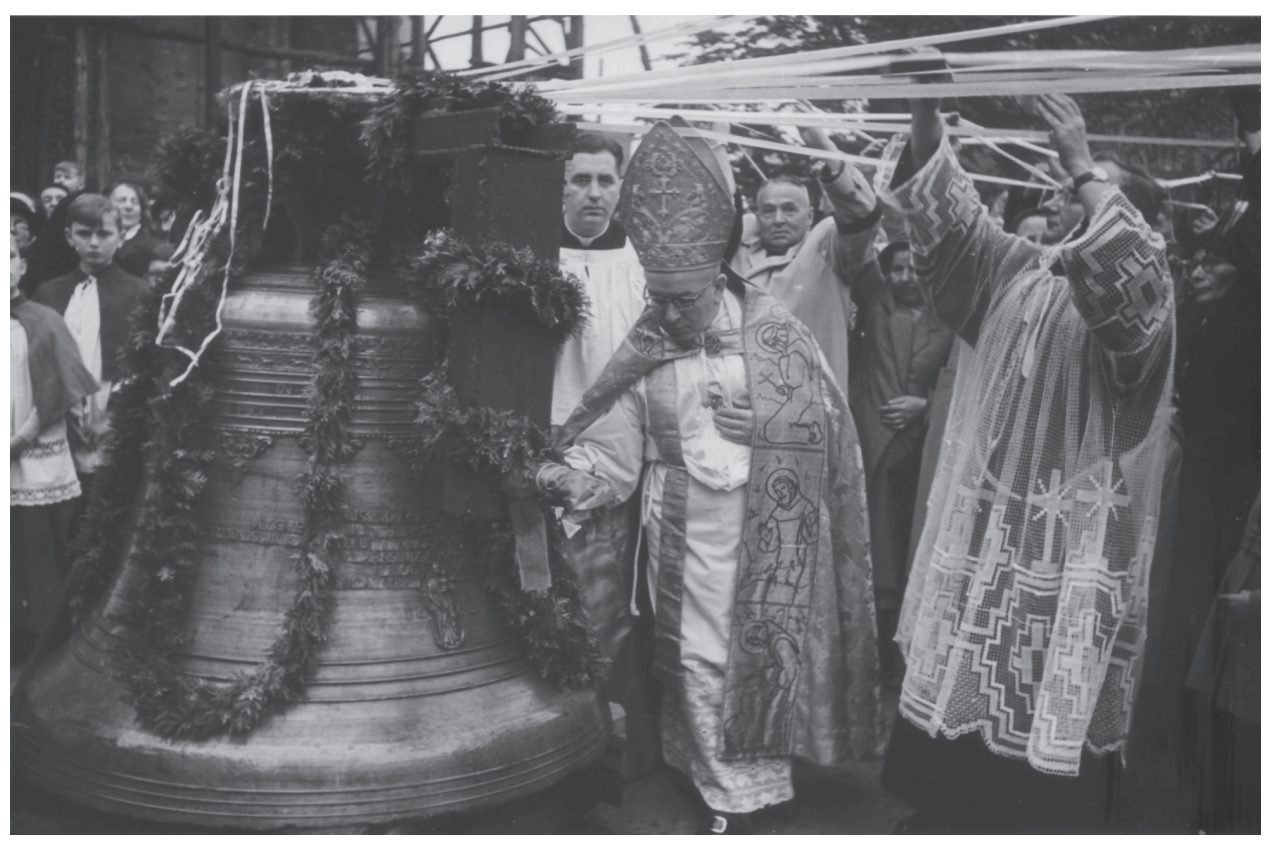

9. Poświęcenie dzwonów przez bp. Franciszka Jedwabskiego, 22.09.1957. Fot. Laskowski

Na wieżach poznańskiego kościoła bernardynów do 1939 r. wisiały trzy dzwony. Na początku II wojny światowej Niemcy wywieźli je w głąb Rzeszy z przeznaczeniem na cele wojenne. Na szczęście części zagrabionych na naszych ziemiach dzwonów Niemcy nie zdążyli zużyć na cele militarne. Po wojnie zostały one odnalezione w Hamburgu, w 1955 r. przywieziono je do Poznania i złożono na placu przed katedrą. Okazało się, że wśród nich były dwa dzwony z kościoła bernardyńskiego, a rozpoznał je o. Damascen Janosz ${ }^{62}$ w czasie niedzielnego spaceru. Po przetransportowaniu na teren klasztorny przeleżały tam dwa lata. W lutym 1957 r. zostały przewiezione do firmy Piotra Materzoka w Zawadzie na Górnym Śląsku celem oczyszczenia z wiekowego osadu i uzbrojenia w jarzma i serca. Do Poznania powróciły 17 lipca tegoż roku. Dnia 4 IX 1957 r. T. Wysocki, znawca ludwisarstwa, stwierdził, że oprawa dzwonów, tj. jarzma żelazne, serca i łożyska z uchwytami wyko-

${ }^{62}$ Robert Janosz, imię zakonne Damascen, ur. 1912, do Zakonu Braci Mniejszych w Prowincji Wniebowzięcia NMP wstąpił w 1930, pierwsze śluby zakonne złożył w 1932, śluby wieczyste (uroczyste) w 1935, święcenia kapłańskie otrzymał w 1937, w latach 1937-1939 i 1945-1946 studiował prawo kanoniczne na KUL i tam w 1939 uzyskał magisterium, a w 1946 licencjat. Od 1947 wykładał prawo kanoniczne w zakonnym seminarium we Wrocławiu Karłowicach, a od 1949 w Katowicach Panewnikach. Zmarł w 1993 i został pochowany na cmentarzu zakonnym w Panewnikach. 
nane są fachowo i solidnie, tak że nie ma obawy o wypadek czy uszkodzenie dzwonów. On też wycenił wartość dzwonów na 500-600 tysięcy ówczesnych złotych, a oprzyrządowanie na 120-140 tysięcy złotych. Równocześnie dokonał pomiaru dzwonów: dzwon dwojga imion św. Franciszka z Asyżu i św. Jana Kapistrana ma 147 cm wysokości i $161 \mathrm{~cm}$ szerokości, czyli średnicy, a dzwon Niepokalanego Poczęcia NMP pochodzący z 1663 r. ma 128 cm średnicy i $123 \mathrm{~cm}$ wysokości ${ }^{63}$.

Poświęcenie dzwonów odbyło się w niedzielę, 22 września 1957 r. Aktu tego dokonał biskup sufragan poznański Franciszek Jedwabski. W uroczystości wzięło udział wielu znakomitych gości świeckich i duchownych. Dzwony zostały wciągnięte na wieże przez firmę PKS. Dzwon większy został zawieszony w wieży od strony północnej, czyli od strony klasztoru, mniejszy zaś w wieży południowej, czyli od strony kaplicy Matki Bożej Loretańskiej. Po raz pierwszy odezwały się w uroczystość św. Franciszka z Asyżu, 4 października 1957 roku $^{64}$.

\section{Przejawy działalności}

Równocześnie z pracami przy odbudowie kościoła i klasztoru poznańscy franciszkanie prowadzili normalną działalność duszpasterską najpierw w kaplicy Matki Bożej Loretańskiej, a później w kościele. Od 1 I 1954 r. codziennie śpiewane były Godzinki ku czci NMP: w dni powszednie o godz. 6 rano, a w niedziele o godz. 6.30. Wieczorem odmawiano dziesiątkę różańca św. Przed uroczystością Matki Bożej Loretańskiej, która przypada 10 grudnia, odprawiano nowennę, w czasie której głoszono kazania o tematyce maryjnej. W samą uroczystość sumę odpustową odprawiali i kazania głosili franciszkanie konwentualni ze Wzgórza Przemysła w Poznaniu ${ }^{65}$. Na szczególną uwagę zasługuje tzw. pogotowie spowiedziowe, albo inaczej mówiąc, dyżur spowiedziowy, zaprowadzony w 1949 r. na życzenie ks. arcybiskupa Walentego Dymka ${ }^{66}$. Konfesjonał dyżurującego umieszczono w kaplicy Matki Bożej Loretańskiej i za pomocą dzwonka można było przywołać spowiednika. Była to pierwsza tego typu inicjatywa duszpasterska w Polsce powojennej. Za przykładem franciszkanów poszły później inne zakony i parafie, z parafią far-

${ }^{63}$ AKP, Kronika, s. 16.

${ }^{64}$ Tamże, s. 17.

${ }^{65}$ Tamże, s. 68; S.B. Tomczak, Kult Matki Bożej Loretańskiej u Franciszkanów (OFM) w Poznaniu, [w:] Kult Pani Ziemi Wejherowskiej w Duchowej Stolicy Kaszub. Materiały z sesji naukowej z okazji X-lecia koronacji obrazu Matki Bożej Wejherowskiej, Wejherowo, 4 czerwca 2009, red. A.R. Sikora, Wejherowo 2010, s. 100-109.

${ }^{66}$ AKP, Kronika, s. 2. 
ną na czele. Ta praktyka przyniosła franciszkanom z poznańskiego kościoła św. Franciszka zasłużoną sławę. Mówiono niekiedy, że ten kościół jest konfesjonałem Poznania. W trzecią niedzielę po Zesłaniu Ducha Świętego 1956 r. została otwarta i poświęcona krypta Krzyża Świętego, usytuowana przy samym wejściu do kościoła. Stała się ona miejscem słuchania spowiedzi św. ${ }^{67}$

Zgodnie z wielowiekową tradycją franciszkańską, zapoczątkowaną przez św. Franciszka z Asyżu w 1223 r. w Greccio ${ }^{68}$, na Boże Narodzenie 1949 r. zbudowano w kościele pierwszy żłóbek. Figury Matki Bożej, św. Józefa oraz aniołów wykonał rzeźbiarz Franciszek Masorz z Rybnika, a figury pasterzy br. Leonard Bannert. Żłóbek od razu wzbudził wielkie zainteresowanie zarówno wśród księży, jak i ludzi świeckich. W okresie bożonarodzeniowym nieprzeliczone thumy wiernych z Poznania i okolicy codziennie nawiedzały kościół. W niedzielę liczba wiernych była jeszcze większa ${ }^{69}$.

W 1949 r. msze św. odprawiano w kaplicy Matki Bożej Loretańskiej w dni powszednie o godz. 6.30 i 8, w niedziele i święta o godz. 7, 9 i 11 oraz nieszpory o 17. Po przeniesieniu służby Bożej do kościoła, co nastąpiło w 1950 r., odprawiano mszę św. także o godz. 12.30. Od 1 I 1954 r. codziennie rano o godz. 6 śpiewano Godzinki o Matce Bożej. Od początku odprawiano wszystkie tradycyjne nabożeństwa franciszkańskie, a więc we wtorek ku czci św. Antoniego z Padwy rano i wieczorem, w sobotę ku czci Matki Bożej, również rano i wieczorem. Przed uroczystościami św. Franciszka z Asyżu i Niepokalanego Poczęcia NMP odprawiano nowennę, w maju nabożeństwa maryjne, w czerwcu ku czci Najświętszego Serca Jezusowego, w każdy piątek Wielkiego Postu drogę krzyżową, w niedziele tego okresu liturgicznego gorzkie żale z kazaniem pasyjnym; w Adwencie codziennie odprawiana była msza św. roratnia. Mieszkańcy Poznania od samego powrotu zakonników licznie uczęszczali do ich kościoła, o czym świadczy wzrastająca z każdym rokiem liczba

${ }^{67}$ Tamże, s. 11.

${ }^{68}$ Według Tomasza z Celano, pierwszego biografa św. Franciszka, około piętnastu dni przed Bożym Narodzeniem [1223 r.] Biedaczyna wezwał do siebie swego przyjaciela Jana Velito z Greccio i rzekł mu: „Pośpiesz się i pilnie przygotuj wszystko, co ci powiem. Chcę bowiem dokonać pamiątki Dziecięcia, które narodziło się w Betlejem. Chcę naocznie pokazać jego braki w niemowlęcych potrzebach, jak został położony w żłobie i jak złożony na sianie w towarzystwie wołu i osła”. (Życiorys pierwszy św. Franciszka, 84). Nastała noc Bożego Narodzenia. Przybył Franciszek i jego bracia oraz ludzie z pochodniami i świecami. Zastali przygotowane: żłóbek, siano, wołu i osła. Wszystko znajdowało się w niezbyt głębokiej grocie pośród lasu. Zagłębienie w skale, poza żłobem i zwierzętami, mogło pomieścić zaledwie kilka osób: co najwyżej celebrującego mszę i ministrantów (Franciszek służył jako diakon). Tomasz z Celano stwierdza, że za ołtarz posłużył żłób, i wydaje się, że należy to rozumieć dosłownie. Franciszkowe obchody Bożego Narodzenia w Greccio zapoczątkowały pobożny zwyczaj wystawiania z okazji tego święta szopek najpierw w kościołach franciszkańskich, a później także we wszystkich innych kościołach katolickich. Por. Leksykon duchowości franciszkańskiej, Kraków-Warszawa 2016, kol. 66-67.

${ }^{69}$ AKP, Kronika, s. 3. 


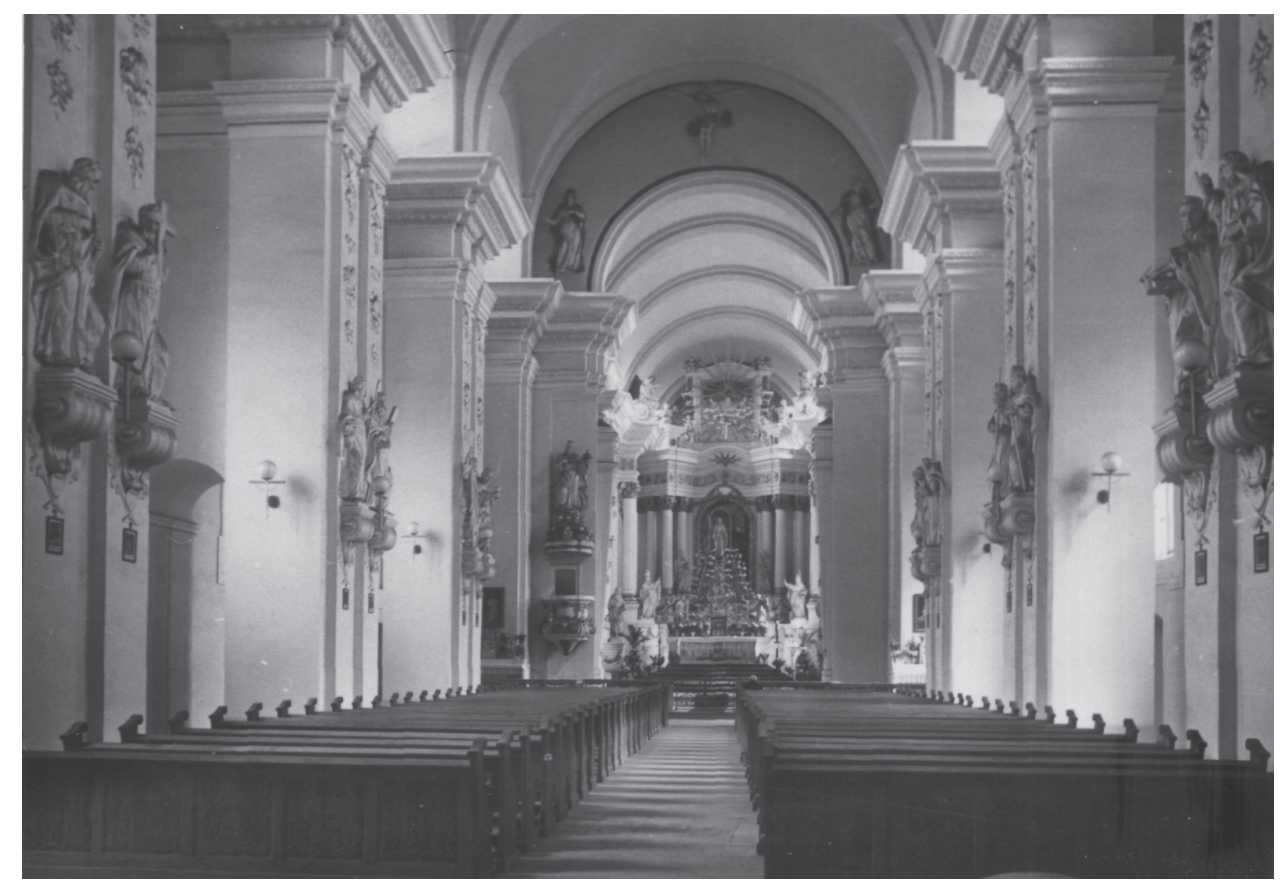

10. Wnętrze kościoła po odbudowie, 1955 r. Fot. Laskowski

udzielonych komunii świętych: w 1949 r. - $58000^{70}$, w 1950 - $68000^{71}, 1951$ $-71000^{72}, 1952-72500^{73}$.

Dnia 1 XI 1950 r., w uroczystość Wszystkich Świętych, papież Pius XII ogłosił nowy dogmat maryjny - Wniebowzięcie NMP i nakazał do litanii loretańskiej dodać wezwanie „Królowo Wniebowzięta - módl się za nami”. To wydarzenie w kościele franciszkanów uczczono specjalnym triduum przed uroczystością Niepokalanego Poczęcia NMP i oktawą po niej. Natomiast w Boże Narodzenie 1949 r. ten sam papież Pius XII ogłosił rok 1950 rokiem Wielkiego Jubileuszu połączonego z możliwością uzyskania odpustu zupełnego. Rok Jubileuszowy zaznaczył się większą frekwencją wiernych w kościele, komunii św. rozdano 71000 ; niestety nie dysponujemy liczbą wysłuchanych wówczas spowiedzi, których było bardzo dużo ${ }^{74}$.

\footnotetext{
70 Tamże, s. 4.

${ }^{71}$ Tamże, s. 5.

72 Tamże, s. 7.

${ }^{73}$ Tamże.

${ }^{74}$ Tamże, s. 5, 7.
} 
Pod koniec lat pięćdziesiątych stopniowo zaczęto w Kościele wprowadzać msze św. wieczorne, co dotychczas nie było praktykowane. Prymas Polski Stefan Wyszyński, na mocy szczególnych uprawnień udzielonych mu przez Stolicę Apostolską, zezwolił i polecił odprawiać mszę św. wieczorne. W poznańskim kościele franciszkanów msze wieczorne zaczęto odprawiać (na co potrzebne było zezwolenie ordynariusza miejsca) już nawet wcześniej, mianowicie od połowy sierpnia 1956 r. w każdy wtorek odprawiano mszę św. o godz. 20 za dobrodziejów kościoła i klasztoru. Uzyskano także zezwolenie na mszę św. wieczorną w pierwszy piątek miesiąca ${ }^{75}$. Był to wstęp do wprowadzenia mszy św. o godz. 20 codziennie i na stałe.

Wydarzeniem godnym odnotowania były msze św. prymicyjne odprawiane najpierw w kaplicy Matki Bożej Loretańskiej, a później także w kościele. I tak w niedzielę, dnia 31 lipca 1949 r., w kaplicy Loretańskiej odbyły się prymicje o. Teodora Turczyńskiego, który po każdej mszy św. udzielał błogosławieństwa prymicyjnego ${ }^{76}$. Dnia 2 VII 1951 r. mszę św. prymicyjną odprawił o. Mateusz Springer oraz o. Serafin Niedbała ${ }^{77}$.

W trudnej sytuacji, w jakiej się znalazł Kościół w Polsce powojennej, w uroczystość Chrystusa Króla dnia 28 X 1951 r. nastąpiło poświęcenie narodu polskiego Najświętszemu Sercu Pana Jezusa. Do tego aktu przygotowano się przez cały tydzień. Codziennie odbywały się specjalne nabożeństwa, podczas których były wygłaszane kazania na wyznaczone tematy ${ }^{78}$.

Uroczystości kościelne często uświetniali swoim śpiewem klerycy Arcybiskupiego Seminarium Duchownego oraz chór ks. Gieburowskiego pod dyrekcją Stefana Stuligrosza. Tak było podczas poświęcenia kościoła 4 X $1951 \mathrm{r}$. Klerycy śpiewali podczas mszy św., a wspomniany chór podczas nieszporów ${ }^{79}$. Dnia 14 I 1951 r. o godz. 18 odbył się koncert kolęd w wykonaniu chóru S. Stu$\operatorname{ligrosza}^{80}$.

Oprócz pracy we własnym kościele ojcowie pomagali w wielu parafiach, głosząc kazania odpustowe lub okolicznościowe, tridua, rekolekcje i misje ludowe, rekolekcje dla sióstr zakonnych i zakonników, często pomagali w słuchaniu spowiedzi św. Najbardziej aktywny na tym odcinku był gwardian poznański, o. Romuald Warzecha, który rocznie wygłaszał średnio około 20 serii rekolekcji i misji ludowych. Oprócz o. Romualda inni ojcowie z klasztoru poznańskiego w 1950 r. przeprowadzili 3 serie misji ludowych, odnowienie misji - 7, rekolekcji ludowych - 9, zakonnych - 4, pomocy innego rodza-

\footnotetext{
75 Tamże, s. 12.

76 Tamże, s. 4.

77 Tamże, s. 7.

78 Tamże.

79 Tamże, s. 4.

80 Tamże, s. 6.
} 
ju - 3. Razem 26 pozycji. Ta apostolska praca była wówczas podejmowana w następujących miejscowościach: Bytom, Tychy, Katowice, Gliwice, Mosina, Szczecin, Jarocin, Szeroka, Ostrów Wlkp., Bykowina ${ }^{81}$.

\title{
Zakończenie
}

Ksiądz Jan Kanty Noryśkiewicz w artykule z okazji stulecia kasaty kościoła i klasztoru bernardynów w Poznaniu napisał: „Trzynawowy kościół OO. Bernardynów znany był w Poznaniu jako jeden z najpiękniejszych" 82 . Z kolei w książce ks. Kamila Kantaka Bernardyni polscy, czytamy że „te wysmukłe wieże [kościoła bernardynów] stanowią przedziwną ozdobę miasta"83. Zarówno kościół z całym swoim bogatym wyposażeniem, jak również wieże kościoła zostały zniszczone w czasie II wojny światowej. W 1947 r., po 111 latach nieobecności, powrócili do Poznania franciszkanie i objęli zniszczony w 75\% kościół i klasztor pobernardyński, po czym z niezwykłą odwagą i determinacją przystąpili do dzieła odbudowy. Najpierw odbudowano kaplicę Matki Bożej Loretańskiej, następnie kościół i na koniec klasztor. Równocześnie zakonnicy prowadzili ożywioną działalność duszpasterską w swoim kościele oraz w bliższych i dalszych parafiach.

\author{
THE CHURCH OF ST. FRANCIS OF ASSISI \\ AND THE FRANCISCAN MONASTERY IN POZNAŃ \\ IN THE YEARS 1947-1957
}

\section{Summary}

In 1947 after 111 years of absence the Franciscans returned to Poznań and reclaimed their former monastery and church dedicated to St. Francis of Assisi, which was destroyed during World War II in 75\%. By 1957 they managed to rebuild the chapel of Our Lady of Loreto, the church and the monastery. From the beginning they conducted ministry in their church as well as preached at the popular missions and retreats in many parishes. On the request of the Poznan Archbishop Walenty Dymek, in 1947 they started a continual confessional duty. Referring to an old tradition initiated by St. Francis of Assisi, from 1949 onwards during the Christmas season they

${ }^{81}$ Tamże, s. 5.

82 J.K. Noryśkiewicz, Sekularyzacja klasztoru OO. Bernardynów w Poznaniu. Wspomnienie w setna rocznice, „Kronika Miasta Poznania”, R. 12 (1934), nr 2, s. 147.

${ }^{83}$ K. Kantak, Bernardyni polscy, t. 2, Lwów 1933, s. 398. 
build an imposing crèche which attracts large crowds of the faithful. The more important ecclesial celebrations were accompanied by the singing of the seminarists of the Poznań seminary and the choir directed by Stefan Stuligrosz.

Słowa kluczowe: Poznań, kościół św. Franciszka z Asyżu, kaplica Matki Bożej Loretańskiej, klasztor franciszkanów/bernardynów, dzwony, organy, stały dyżur spowiedziowy.

Keys words: Poznań, St. Francis of Assisi Church, Our Lady of Loreto Chapel, Franciscan/Bernardine monastery, bells, organ, continual confessional duty

\section{BIBLIOGRAFIA}

\section{ŹRÓDLA ARCHIWALNE}

\section{Archiwum Klasztoru Braci Mniejszych w Poznaniu}

Kronika Klasztoru OO. Franciszkanów w Poznaniu, maszynopis bez sygnatury.

Zapiski do kroniki klasztornej o. Romualda Warzechy, rękopis bez sygnatury.

\section{ŹRÓDŁA DRUKOWANE}

Jan z Komorowa, Kronika Zakonu Braci Mniejszych obserwantów (1209-1536), Kalwaria Zebrzydowska 2014.

Kroniki Bernardynów poznańskich, oprac. S.B. Tomczak, J. Wiesiołowski, Poznań 2002.

\section{OPRACOWANIA}

Chadam A., Poznań, [w:] Klasztory bernardyńskie w Polsce w jej granicach historycznych, Kalwaria Zebrzydowska 1985, s. 266-274.

Czechlewski M.P., Wielkie organy Michała Englera Młodszego w kościele bernardynów w Poznaniu, „Studia Franciszkańskie”, 18 (2008), s. 317-327.

Dolczewski Z., Działalność warsztatu intarsjerskiego brata Hilariona z Poznania, „Studia Muzealne", R. VIII, Poznań 1970, s. 59-87.

Figuła-Czech J., Leśniewska D., Odbudowa i rekonstrukcja kościoła i klasztoru OO. Bernardynów, „Kronika Miasta Poznania”, 2005, nr 2.

Kantak K., Bernardyni polscy, t. 2, Lwów 1933.

Leksykon duchowości franciszkańskiej, Kraków-Warszawa 2016.

Noryśkiewicz J.K., Sekularyzacja klasztoru OO. Bernardynów w Poznaniu. Wspomnienie w setna rocznice, ,Kronika Miasta Poznania”, R. 12 (1934), nr 2.

Raport o stratach wojennych Poznania 1939-1945, red. A. Sakson, A. Skarzyński, Poznań 2008.

Tomczak S.B., Jan Kapistran Szysiecki, zastużony bernardyn poznański z przełomu XVII i XVIII stulecia, „Ecclesia. Studia z Dziejów Wielkopolski”, t. 9 (2014), s. 127-152.

Tomczak S.B., Kult Matki Bożej Loretańskiej u Franciszkanów (OFM) w Poznaniu, [w:] Kult Pani Ziemi Wejherowskiej w Duchowej Stolicy Kaszub. Materiały z sesji naukowej z okazji X-lecia koronacji obrazu Matki Bożej Wejherowskiej, Wejherowo, 4 czerwca 2009, red. A.R. Sikora, Wejherowo 2010, s. 100-109. 